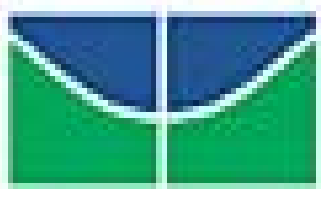

UNIVERSIDADE DE BRASÍLIA

Centro de Excelência em Turismo

Pós-Graduação Latu Sensu

Curso de Especialização em Turismo e Desenvolvimento Sustentável

\title{
A comunidade local e a atividade turística na área da Praia Grande em São Luís (MA)
}

Kiara Mesquita de Azevedo

Prof ${ }^{a}$. Dra . Doris Sayago

Brasília - 2007 


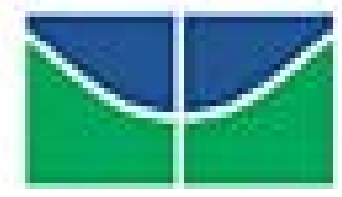

UNIVERSIDADE DE BRASÍLIA

Centro de Excelência em Turismo

Pós-Graduação Latu Sensu

Curso de Especialização em Turismo e Desenvolvimento Sustentável

\section{A comunidade local e a atividade turística na área da Praia Grande em São Luís (MA)}

Kiara Mesquita de Azevedo

Profa $^{a}$. Dra ${ }^{a}$. Doris Sayago

Monografia apresentada ao Centro de Excelência em Turismo - CET, da Universidade de Brasília - UnB, como requisito parcial à obtenção do grau de Especialista em Turismo e Desenvolvimento Sustentável. 


\section{Azevedo, Kiara Mesquita}

A comunidade local e a atividade turística na área da Praia Grande em São Luís (MA) / Kiara Mesquita de Azevedo. - Brasília, 2007.

\section{$62 \mathrm{f}$. il.}

Monografia (Pós-graduação Lato Sensu) - Curso de Especialização em Turismo e Desenvolvimento Sustentável - Universidade de Brasília , 2007.

1. Comunidade local 2. Turismo Cultural 3. Sustentabilidade - Praia Grande I. Título.

CDD: 650.3 


\section{UNIVERSIDADE DE BRASÍLIA}

Centro de Excelência em Turismo

Pós-Graduação Latu Sensu

Curso de Especialização em Turismo e Desenvolvimento Sustentável

Kiara Mesquita de Azevedo

Aprovado por:

Professora Orientadora Dra. Doris Sayago

Professora Msc. Ariadne Bittencourt

Professor Dr. Umberto Euzébio

Brasília, 10 de maio de 2007. 
Aos meus pais, por acreditarem nos meus sonhos. 


\section{AGRADECIMENTOS}

À Professora Doutora Doris Sayago, pela orientação;

Ao meu pai, José Carlos de Azevedo Filho, pela revisão do texto e, consequentemente, pela melhoria da clareza nas frases;

Aos colegas de curso que colaboraram na realização deste trabalho;

A todos os novos amigos que fiz em Brasília e fizeram deste curso uma das minhas grandes experiências de vida. 


\section{RESUMO}

O presente trabalho visa analisar a realidade da comunidade local da área da Praia Grande em relação ao desenvolvimento da atividade turística na região e a sustentabilidade da atividade. O objeto de estudo é a comunidade local da Praia Grande, ambiente escolhido para a realização do estudo por sua relevante simbologia quando tratamos de Turismo Cultural e Patrimônio na cidade de São Luís (MA). O trabalho foi fundamentado em bibliografia e em observações realizadas na área em questão. Como considerações, a percepção da comunidade em relação ao desenvolvimento do turismo local.

Palavras-chave: Comunidade Local - Turismo Cultural - Sustentabilidade - Praia Grande. 


\begin{abstract}
The present work aims at to analyze the reality of the local community of the area of the Praia Grande in relation to the development of the tourist activity in the e region the sustainable of the activity. The study object is the local community of the Praia Grande, surrounding chosen for the accomplishment of the study for its excellent symbology when we deal with Cultural Tourism and Patrimony in the city of São Luís (MA). The work was based on bibliography and comments carried through in the area in question. How consideration, the perception of the community in relation to the development of the local tourism.
\end{abstract}

Word-key: Local community - Cultural Tourism - Sustentabilidade - Praia Grande. 


\section{LISTA DE ABREVIATURAS E SIGLAS}

BIRD - Banco Interamericano de Desenvolvimento

ICOMOS - Conselho Internacional de Monumentos e Sítios

IPCC - Painel Intergovernamental de Mudanças Climáticas

IUCN - União Mundial para a Natureza

IPHAN - Instituto do Patrimônio Histórico e Artístico Nacional

IPES - Instituto de Pesquisa Especial para a Sociedade

OMT - Organização Mundial do Turismo

ONU - Organização das Nações Unidas

PRODETUR - Programa de Desenvolvimento do Turismo no Nordeste

PNUMA - Programa das Nações Unidas para o Meio Ambiente

UNESCO - Organização das Nações Unidas para a Educação, a Ciência e a Cultura 
1 INTRODUÇÃO

2 TURISMO E DESENVOLVIMENTO SUSTENTÁVEL .....................11

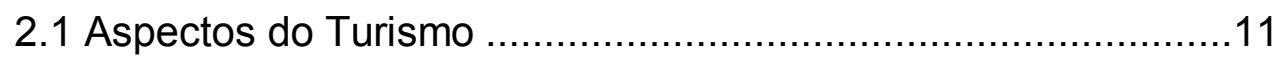

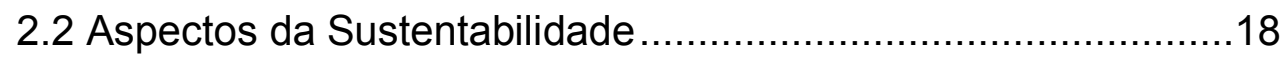

2.3 Turismo e Desenvolvimento Sustentável .................................22

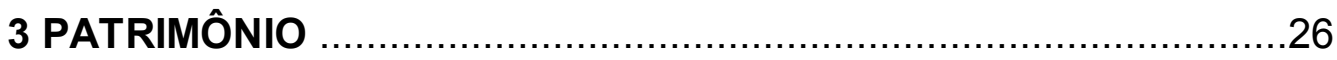

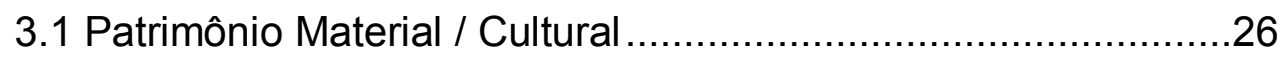

3.2 Patrimônio Cultural, Turismo e Desenvolvimento .....................29

4 CENTRO HISTÓRICO DE SÃO LUÍS/MA - A ÁREA DA

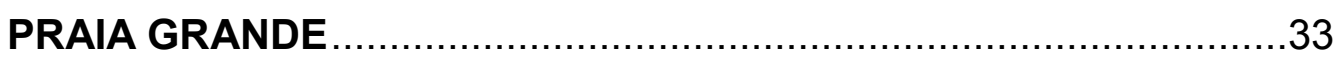

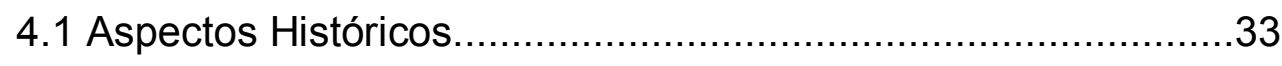

4.2 O Patrimônio Cultural na Praia Grande....................................39

5 A REALIDADE DA PRAIA GRANDE:

Turismo X Sustentabilidade, aspectos sócio-culturais ..................47

5.1 A Atividade Turística na Praia Grande ...................................47

5.2 A Comunidade e a Atividade Turística......................................51

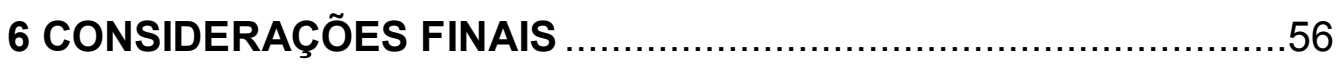

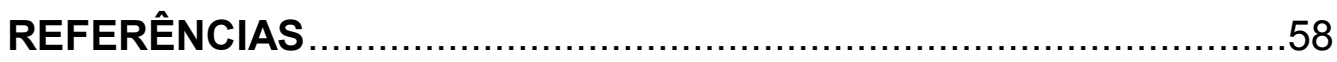




\section{1 - INTRODUÇÃO}

Em 1997, o Centro Histórico da Cidade de São Luís recebeu o título de Patrimônio Cultural da Humanidade em decorrência do tombamento pela UNESCO. Essa titulação proporcionou verdadeiras transformações no bairro da Praia Grande e em sua população. Dentre estas transformações merecem destaque as obras de revitalização e restauração da localidade e o aumento de sua comercialização como produto turístico.

Em pesquisa realizada junto a representantes da comunidade da Praia Grande no ano de 1997, ano da titulação, ficou comprovado que a percepção dessas pessoas sobre a nova realidade do bairro era quase inexistente. Em 2005, nova pesquisa constatou que a realidade não mudara nos oito anos que separam as pesquisas.

Após as diversas mudanças, inovações, oportunidades e problemas, concluiu-se que não existe a noção de valor sobre a questão do patrimônio histórico e que não se identifica, nessa comunidade, princípios de quem vive em local tombado como Patrimônio Cultural da Humanidade.

Considerando os princípios da sustentabilidade, podemos afirmar que essa não é a realidade da atividade turística ali desenvolvida, pois a comunidade não é atuante nos processos de decisão referentes a intervenções de cunho turístico a se realizarem na região, muitas das vezes nem tomando conhecimento de atividades realizadas e que tenham influência direta em sua realidade.

A área objeto do estudo é de uso comum e de grande fluxo da comunidade ludovicense onde também se concentra grande parte da atividade cultural e dos atrativos históricos da cidade. O local foi escolhido pela sua relevante simbologia perante o tema abordado.

O conhecimento sobre a área é, de certa forma, relevante, baseado em bibliografia que destaca o seu aspecto histórico, além do conhecimento obtido por meio de diversos trabalhos realizados tendo a região como foco de estudo. 
Freqüentar o local nos faz buscar maneiras de entender melhor sua realidade, compreender o real valor que resultou na titulação de patrimônio da humanidade e, posteriormente, difundir essa idéia.

Como objetivo principal, busca-se analisar a atual situação da sustentabilidade, sob uma perspectiva turística, no bairro da Praia Grande. Conseqüentemente a isso, despertar o interesse dos indivíduos para a importância de cada um na preservação/conservação dos bens tombados e aumentar a participação dos indivíduos no processo de preservação da área.

Para a coleta das informações utilizar-se-á, basicamente, consulta bibliográfica e banco de dados composto por outros trabalhos realizados com o objeto de estudo, além da internet. Também foram realizadas visitas ao local de estudo para observação da realidade e melhor percepção das necessidades referentes à proposta. As visitas foram realizadas em diferentes períodos no ano, considerando a sazonalidade do fluxo turístico e em diferentes turnos com o objetivo de avaliar a região em diferentes aspectos.

O trabalho se apresenta em quatro partes. A primeira, intitulada "Turismo e Desenvolvimento Sustentável”, retrata aspectos sobre o turismo, a sustentabilidade e a interlocução desses dois elementos. A segunda, denominada "Patrimônio", apresenta informações sobre o patrimônio cultural/material e a relação desse patrimônio com o turismo e o desenvolvimento de uma localidade. A terceira, aborda características do objeto de estudo, o bairro da Praia Grande, em São Luís (MA), sua história, seu patrimônio, e, por fim, a quarta parte analisa a sustentabilidade relacionando o turismo com a comunidade local.

As impressões e considerações sobre o trabalho estão disponíveis no item "Considerações Finais".

Com isso, tem-se a oportunidade de proporcionar um levantamento dos aspectos da sustentabilidade relacionada à atividade turística no bairro da Praia Grande, considerando principalmente seu patrimônio cultural. 


\section{TURISMO E DESENVOLVIMENTO SUSTENTÁVEL.}

\subsection{Aspectos do Turismo.}

O Turismo é uma atividade complexa que envolve diversas outras áreas em sua formação, tais como economia, história, psicologia, geografia, antropologia, cultura, apenas para citar alguns dos aspectos formadores dessa atividade.

Essa complexidade da atividade e os diferentes interesses envolvidos são fatores que não permitem a generalização de seu conceito.

Andrade (2002, p.12) apresenta como fundamental, antes de qualquer observação referente à atividade turística, o seguinte princípio:

"o homem, o espaço e o tempo constituem os três pré-requisitos para qualquer reflexão equilibrada a respeito do fenômeno, cuja anatomia conjuntural e sintônica compõe-se de modo compulsório, porque sem sua tríplice existência e sua permanente concorrência não há possibilidade alguma de existir, lógica e ontologicamente, qualquer manifestação do fenômeno turístico" (ANDRADE, 2002, p. 12, grifo do autor)

Isso nos remete à dinâmica do Turismo, à sua necessidade de ser constantemente analisado e avaliado, inclusive para a reformulação de políticas públicas.

A OMT define, atualmente, o Turismo como as atividades que as pessoas realizam durante suas viagens e estadias em lugares diferentes do de sua moradia habitual, por um período de tempo contínuo inferior a um ano, com fins de lazer, por negócios ou outros motivos não relacionados com o exercício de uma atividade remunerada no lugar visitado (AGUIAR \& DIAS, 2002).

O Código Mundial de Ética do Turismo, de 1999, apresenta o Turismo como um direito comum a todo e qualquer cidadão, nos termos do artigo 7.1 abaixo transcrito: 
"Artigo 7. Direito do Turismo

7.1 A possibilidade de acesso direto e pessoal à descoberta das riquezas de nosso mundo constituirá um direito aberto, igualmente, a todos os habitantes do planeta. A participação cada vez mais ampla no turismo nacional e internacional deve ser considerada como uma das melhores expressões possíveis do crescimento contínuo do tempo livre, e não deve ser dificultada."

Viajando cria-se uma forma mais consciente de ver o próximo e os diversos modos de vida existentes no planeta. Pode-se vivenciar a estrutura social de uma localidade, sua história econômica, sua geografia, bem como as mentalidades de seu povo.

Considerando o Turismo em seu aspecto econômico, nota-se que ele utiliza como matéria-prima paisagens ou cenários do patrimônio natural e cultural.

Em relação aos recursos utilizados, Andrade (2002, p.101) afirma que:

"O turismo faz com que os bens naturais e culturais se tornem atrativos e objeto do fenômeno, sem desgastes sistemáticos ou consumação total; colabora para a redução de bens e prestação de serviços pela ativação do contingente de mão-de-obra especializada e não-especializada; necessita de bens de capital e de capital de giro para garantir o sucesso das aplicações e a maior rentabilidade dos empreendimentos."

O mesmo autor relata que, em relação aos resultados que produz, o turismo:

- É lucrativo aos indivíduos e às empresas que se dedicam à produção de bens e à prestação de serviços;

- Permite boa captação de divisas na balança de pagamentos, nas atividades turísticas de natureza receptiva a nível internacional;

- Recolhe impostos, contribuições e taxas diversas em todos os tipos de operação que realiza;

- Propicia a valorização dos recursos naturais e artificiais e os equipamentos à disposição;

- Incentiva o progresso econômico local, regional e nacional pelo desenvolvimento empresarial, que garante o emprego de um número 
significativo de profissionais dos vários setores de produção e dos diferentes segmentos sociais.

Mas o turismo também está diretamente relacionado à cultura de um povo, entendida esta como "aquele todo complexo que inclui conhecimento, crenças, arte, moral, direito, costumes e outras capacidades e hábitos adquiridos pelo homem como membro da sociedade" (TAYLOR, 1871, apud AGUIAR \& DIAS, 2002, p.130).

Esse conjunto de hábitos, usos e costumes, modos de vida cotidiana que formam a sociedade, também é beneficiado pela atividade turística.

Segundo Barretto (2000, p. 23),

"As formas como o turista vai entrar em contato com esse lugar e sua
interação que terá com ele constituem, atualmente, os grandes
parâmetros para a classificação dos turistas e seu enquadramento
em categorias socioantropológicas. Também será a interação entre o
turista e o lugar que indicará os tipos de turismo mais adequados
para otimizar a proteção do meio ambiente, tanto natural quanto
cultural, do núcleo receptor. "

O aumento do conhecimento das culturas locais; o aumento dos contatos sociais produzidos com a chegada dos visitantes, além do estímulo propiciado por este aumento para a circulação de novas idéias e valores na comunidade receptora; a sobrevivência da cultura local pela valorização do artesanato, música, entre outros; a criação de muitos serviços úteis facilitando a vida da população; a maior valorização do patrimônio histórico e a troca cultural entre os diferentes povos, enfatizando a já citada compreensão e tolerância frente às diferenças, são alguns dos benefícios que a atividade turística proporciona.

O Turismo, que tem como oferta principal a cultura e a história de um destino, tem contribuído para a manutenção de prédios, bairros e até mesmo de cidades, evitando sua substituição por novas formas arquitetônicas.

A recuperação dessa memória, tanto no aspecto arquitetônico como em outros aspectos da cultura, por motivação da atividade turística, leva, posteriormente, a uma recuperação da cultura local, a sua valorização. 
Entretanto, como toda atividade, o Turismo também gera problemas. Cada vez mais se percebe a necessidade de atenção para as áreas da cultura material, na verificação dos seus efeitos em relação a bens culturais, como o patrimônio histórico.

No aspecto sociocultural, pode provocar uma alteração profunda na comunidade local, suscitando a perda de seu orgulho e identidade cultural. Isso pode acontecer quando a comunidade começa a fazer uso de hábitos e costumes dos visitantes, abdicando das suas próprias características.

Também existe o risco de adoção de costumes e comportamentos por meio da juventude da comunidade receptora, os quais são trazidos pelos visitantes, conflitando com a realidade da qual faz parte. São colocados em risco crenças e valores sociais consolidados ao longo dos tempos.

A cultura pode se tornar algo meramente comercial, tendo suas características e motivações originais modificadas, gerando o declínio da produção artística local. É extremamente importante, ao se planejar a atividade turística para uma determinada localidade, considerar a significação de crenças, valores, normas e sanções, símbolos, idioma e tecnologia, elementos que são os formadores de sua cultura.

Barretto (2000, p.8) destaca que,

“...nos últimos anos, a compreensão de que a cultua material também sofre degradação se submetida a uma visitação excessiva e a um uso inadequado levou a que se passasse a tentar aplicar ao turismo histórico o paradigma do desenvolvimento sustentável [...]."

Em 1995, realizou-se em Lanzarotte, nas Ilhas Canárias, Espanha, a Conferência Mundial de Turismo Sustentável, e entre as apelações à comunidade internacional, em especial aos governos, e até mesmo ao próprio turista, formulouse a seguinte regra:

Artigo 3 - a atividade turística deverá considerar os efeitos induzidos sobre o patrimônio cultural e os elementos, atividades e dinâmicas tradicionais das comunidades locais. O reconhecimento destes fatores locais e o apoio a sua 
identidade, cultura e interesses, devem ser referências obrigatórias na formulação das estratégias turísticas, especialmente nos países em via de desenvolvimento.

O turismo e a cultura estão estreitamente relacionados, existindo, inclusive, um tipo de turismo denominado Turismo Cultural, cuja motivação é a busca por conhecimentos sobre a localidade visitada e a sua comunidade. Esse tipo de turismo reflete uma das áreas de segmentação do mercado turístico e o produto da segmentação busca facilitar a identificação de clientes com comportamentos homogêneos quanto a seus gostos e preferências. A segmentação possibilita o conhecimento dos principais destinos geográficos, dos tipos de transporte, da composição demográfica dos turistas e da sua situação social e estilo de vida, entre outros elementos" (ANSARAH, 2001, p.27, apud AGUIAR \& DIAS, 2002, p. 29).

A partir da segmentação, têm-se dois grandes grupos: o do turismo natural (com atrativos relacionados à natureza) e o do turismo cultural (com atrativos relacionados aos aspectos da cultura humana).

O turismo é um estímulo à manutenção da identidade de uma população. É possível a convivência harmoniosa entre a atividade e o legado cultural por intermédio do planejamento. Desta forma, cidades e prédios históricos, bem como monumentos e manifestações culturais, são trabalhados como produtos turísticos de maneira responsável, sem grandes impactos para o turista ou para a comunidade receptora.

O turismo é uma atividade que apresenta diversidade de formas e tipos. Esses tipos são definidos de acordo com a motivação do viajante para o deslocamento.

Para Andrade (2002, p. 95),

"O turista, como qualquer outra pessoa, exerce a ambivalente e concomitante função de agente aculturador e de elemento suscetível de sensibilização por culturas outras que a sua própria. Assim, pelo próprio desejo ou pela necessidade de participar de ambientes e sociedades diferentes dos que lhe são próprios, ele se dispõe a interferir e a integrar-se, em um processo cultural, como elemento ativo e passivo de influência." 
Esse desejo, a essa necessidade de transferência cultural, chama-se motivação cultural. Quando a motivação da viagem é a disposição de conhecer, pesquisar, analisar dados, obras ou fatos em suas variadas manifestações, está em prática o Turismo Cultural.

O Turismo Cultural pode ser considerado uma atividade de lazer com caráter educacional, que colabora para o aumento da consciência dos visitantes e sua apreciação da cultura local. Conglomera todos os aspectos da viagem pelos quais o turista conhece a vida e o pensamento da comunidade visitada.

A comunidade, por sua vez, se utiliza de fatores culturais para se "apresentar" ao visitante: seu artesanato, seu folclore, a gastronomia típica, arquitetura histórica, entre outros. Esses aspectos são atrativos importantes, mas sua exploração pode resultar em impactos negativos que podem atingir o seu modo de vida, quando esse modo de viver se modifica para atender à demanda turística existente.

Andrade (2002, p. 71) assim define o Turismo Cultural:

“...atividades que se efetuam através de deslocamentos para a satisfação de objetivos de encontro com emoções artísticas, científicas, de formação e de informação nos diversos ramos existentes, em decorrência das próprias riquezas da inteligência e da criatividade humanas.

O Turismo Cultural faz uso de alguns recursos para sua funcionalidade. Segundo Swarbrooke (2000, p. 36), estes são os recursos:

- Locais associados a acontecimentos históricos e pessoas famosas;

- Cultura popular moderna: locação para filmes, locações feitas para a TV;

- Passeios e itinerários temáticos;

- Comidas e bebidas tradicionais;

- Férias com algum interesse especial;

- Atividades de esporte e lazer: participantes, espectadores, jogos e esportes tradicionais;

- Ofícios tradicionais; 
- Artes: teatros, galerias de artes;

- Tipos de arquitetura;

- Linguagem: idioma nativo predominante, línguas minoritárias e regionais, escolas de línguas;

- Locais religiosos: santuários, igrejas, catedrais;

- Indústria e Comércio: visitação de locais de trabalho, atrações rurais, lojas famosas, mercados, complexos de lojas e atividades de lazer;

- Festivais e eventos especiais: folclore, artes performáticas, esportes, interesse especial;

- Atrações Históricas: museus e centros históricos, castelos, casas majestosas e monumentos antigos, jardins históricos; paisagens históricas, vilarejos históricos e vistas de cidades.

O Turismo Cultural sofre ameaças e pressões de instrumentos da tecnologia como a televisão, a música e o cinema. Com a redução da diversidade cultural propiciada por esses fatores que, de forma rápida e prática, interligam diversos locais do mundo, a motivação de viajar para vivenciar essas diversidades também é reduzida.

Em contrapartida, o turismo cultural é visto como forma de manter as raízes nesses tempos de globalização. É uma ferramenta para valorização e sustentação da cultura local, de suas especificações, fator de grande importância para a qualificação do produto turístico. Trata-se de uma maneira de fazer turismo que, entre outros objetivos, envolve a apreciação de monumentos e sítios históricos, contribuindo para a manutenção e proteção do patrimônio cultural da humanidade.

O ICOMOS, em sua Carta do Turismo Cultural (1976), assim se refere a esse tipo de turismo:

"O Turismo Cultural é aquela forma de turismo cujo objetivo é, entre outros, conhecer monumentos e sítios históricos, mostrando mesmo um efeito positivo difuso - apesar de satisfazer seus próprios fins contribuindo para a preservação deste patrimônio. Esta forma de turismo justifica os esforços pela manutenção e proteção da comunidade humana devido aos benefícios socioculturais e econômicos que propicia à população envolvida (AGUIAR \& DIAS, 2002, p. 205)." 
O turismo cultural ainda é motivo de outras vantagens. Com a prática da atividade ocorre uma valorização econômica dos lugares, a dinamização do comércio local e dos serviços, resultando em novos empregos e aumento de renda. A valorização cultural do lugar ainda proporciona crescimento do orgulho cultural da comunidade receptora, reforçando, desta forma, a sua identidade cultural.

Ryan (1991 apud BURNS 2002, p. 51) destaca que:

"O turismo diz respeito, essencialmente, à experiência do lugar. $O$ "produto" do turismo não é o destino do turista, mas diz respeito à experiência daquele lugar e do que ocorre [o que consiste de] uma série de interações internas e externas".

Enfatizando o patrimônio cultural edificado, este encontra novos usos que assim integram o presente num novo contexto cultural, preservando as características arquitetônicas do passado. É uma forma de acesso à história, à cultura e ao modo de viver de uma comunidade, sendo um tipo de turismo que tem como atrativo principal o conhecimento do acervo cultural das localidades em seus diversos aspectos.

\section{2 - Aspectos da Sustentabilidade}

É notável o desequilíbrio gerado pelo modelo de crescimento econômico adotado na atualidade. A riqueza e a fartura nunca presenciadas em tempos anteriores se confrontam com a miséria, a poluição e a degradação ambiental que se potencializam a cada dia.

Buscando a conciliação entre esse desenvolvimento econômico e a preservação dos ambientes, igualmente visando amenizar as diferenças sociais existentes, nasce, então, a idéia de Desenvolvimento Sustentável (FOLHA ONLINE, 2003).

Os primeiros registros da preocupação com o futuro do meio ambiente e os desgastes resultantes da evolução surgem na década de sessenta, onde se destaca a publicação de "A Primavera Silenciosa" (1962), por Rachel Carlson. A 
obra apresenta a realidade do meio ambiente em não ser capaz de absorver e se proteger dos poluentes e traz as possíveis conseqüências desse comportamento (FUNDAÇÃO BRASILEIRA PARA O DESENVOLVIMENTO SUSTENTÁVEL, 200-).

Na mesma década, destacam-se a realização do Programa Internacional Biológico, objetivando analisar os impactos ambientais, e a realização da Conferência Internacional para o Uso Racional e a Conservação da Biosfera, pela Unesco (FUNDAÇÃO BRASILEIRA PARA O DESENVOLVIMENTO SUSTENTÁVEL, 200-).

Em anos subseqüentes, diversos outros registros de programas, conferências e instituições voltadas ao pensamento do desenvolvimento sustentável foram efetivados. Entre eles, a Conferência das Nações Unidas sobre o Meio Ambiente Humano, organizada pelo PNUMA, realizada em Estocolmo, em 1972, onde pela primeira vez é reconhecida a necessidade de políticas internacionais ambientais.

Nos anos oitenta surge a primeira definição de desenvolvimento sustentável, no documento Nosso Futuro Comum (Relatório Brundtland), que iria então popularizar o conceito. Segundo o documento, desenvolvimento sustentável é "aquele que atende às necessidades do presente sem comprometer a possibilidade de as gerações futuras atenderem as suas próprias necessidades" (COMISSÃO MUNDIAL SOBRE O MEIO AMBIENTE E DESENVOLVIMENTO, 1991, p. 46).

Este documento chamou a atenção do mundo sobre a necessidade urgente de encontrar formas de desenvolvimento econômico que se sustentassem sem a redução dramática dos recursos naturais nem com danos ao meio ambiente. Definiu, também, três princípios essenciais a serem cumpridos: desenvolvimento econômico, proteção ambiental e eqüidade social, sendo que para cumprir estas condições seriam indispensáveis mudanças tecnológicas e sociais.

$\mathrm{Na}$ década seguinte, foi fundado o Instituto Internacional de Desenvolvimento Sustentável. No Brasil, foi criada a Fundação Brasileira para o Desenvolvimento Sustentável, no Rio de Janeiro, já visando a realização da 
Conferência das Nações Unidas sobre o Meio Ambiente e Desenvolvimento - ECO 92.

É importante lembrar que não foi somente de chefes de Estado e de representantes oficiais que se constituiu a Rio-92, pois foi a participação da sociedade civil, de organizações não-governamentais de centenas de países, que fez do Rio uma verdadeira "Babilônia", e foi graças a eles que um importante documento deixado de lado na conferência oficial continuou vivo, passou por reavaliações, comissões internacionais nunca antes pensadas, foi ratificado pela Unesco, e finalmente aprovado pela ONU, em 2002: A Carta da Terra, um documento de importância singular, equivalente à Declaração Universal dos Direitos Humanos para a área de Meio Ambiente, cujo preâmbulo traz os seguintes dizeres:

\footnotetext{
"Estamos diante de um momento crítico na história da Terra, numa época em que a humanidade deve escolher o seu futuro. À medida que o mundo torna-se cada vez mais interdependente e frágil, 0 futuro enfrenta, ao mesmo tempo, grandes perigos e grandes promessas. Para seguir adiante, devemos reconhecer que, no meio da uma magnífica diversidade de culturas e formas de vida, somos uma família humana e uma comunidade terrestre com um destino comum. Devemos somar forças para gerar uma sociedade sustentável global baseada no respeito pela natureza, nos direitos humanos universais, na justiça econômica e numa cultura da paz. Para chegar a este propósito, é imperativo que nós, os povos da Terra, declaremos nossa responsabilidade uns para com os outros, com a grande comunidade da vida, e com as futuras gerações" (FUNDAÇÃO BRASILEIRA PARA O DESENVOLVIMENTO SUSTENTÁVEL, 200-).
}

As ações em prol da sustentabilidade prosseguem nos anos seguintes, gerando acordos como o Protocolo de Kyoto, de 1992, que reforça a Convenção sobre Mudanças Climáticas, ao determinar que os países industrializados reduzam suas emissões de gases de efeito estufa em 6\% a 8\% dos níveis de 1990 até 20082012.

Mais recentemente, em 2002, realizou-se a Cúpula Mundial sobre Desenvolvimento Sustentável, em Johannesburgo, África do Sul. Na ocasião, 104 líderes mundiais e milhares de delegados concordaram com um plano restrito de redução da pobreza e proteção ambiental. 
Como referência a era pós-Kyoto (onde foram estabelecidos compromissos até 2012), prevê-se a utilização do quarto relatório produzido pelo IPCC, Mudanças Climáticas 2007. Durante uma semana, mais de 500 cientistas e representantes governamentais se reuniram a portas fechadas na sede da Unesco, em Paris, para concluir e aprovar o texto sobre as constatações científicas em relação ao aquecimento global. Ao final, os cientistas concluíram que há $90 \%$ de chance de o aquecimento global observado nos últimos 50 anos ter sido causado pela atividade humana. É um aumento expressivo em relação ao último relatório, de 2001, que apontava uma probabilidade de 66\% (SíTIO VEGETARIANO, 2007).

Todas essas ações tiveram como base a idéia de criar um modelo econômico capaz de gerar riqueza e bem-estar enquanto promove a coesão social e impede a destruição da natureza, chegando à premissa mais conhecida da sustentabilidade: satisfazer as necessidades presentes, sem comprometer a capacidade das gerações futuras de suprir suas próprias necessidades.

Segundo a Comissão Mundial sobre o Meio Ambiente e Desenvolvimento (1991, p. 47) “... o desenvolvimento sustentável exige que as sociedades atendam às necessidades humanas, tanto aumentando o potencial de produção quanto assegurando a todos as mesmas oportunidades."

Este modelo, no entanto, vai de encontro ao modelo de produção e consumo ocidentais, que ameaça o equilíbrio do planeta; se preocupa com os problemas em longo prazo, enquanto o atual modelo de desenvolvimento, fundado em uma lógica puramente econômica, se centra no aqui e agora (MENDES, 200-).

Para alguns, falar de desenvolvimento sustentável é se referir exclusivamente sobre sustentabilidade ecológica. No entanto, o desenvolvimento sustentável insinua também uma sustentabilidade social.

O desenvolvimento sustentável é um processo de aprendizagem social de longo prazo, apoiado por políticas públicas. Sendo o desenvolvimento sustentável o objetivo, as populações locais necessariamente têm de ser incorporadas ao processo. 
Em relação ao patrimônio cultural, até a primeira metade do século XIX a idéia de preservação não passava de atitudes isoladas de estudiosos e colecionadores que, aos poucos, foram despertando o interesse das comunidades e de seus representantes a promoveram intervenções voltadas para a preservação de patrimônios históricos e artísticos, e que somente a partir dos primeiros movimentos europeus da segunda metade do século XIX vem recebendo ações preservacionistas sistemáticas tratadas com seriedade em nome de uma memória social. Afinal, "assim, como organismo vivo que nasce e cresce continuamente, a cidade é sensível" (PEREIRA, 1994, p.23).

Adams (1990 apud BURNS, 2002, p. 163) expõe que:

"O desenvolvimento deveria ser o que as comunidades humanas fazem a si mesmas. Na prática, entretanto, ele é o que os estados e seus banqueiros e agentes 'especializados' fazem a essas comunidades, em nome da modernidade, integração nacional, crescimento econômico ou mil outros chavões".

A substituição do modelo econômico tradicional pelo modelo sustentável só será possível a partir de uma ampla e radical mudança de cultura. Caso contrário, as discussões em torno do desenvolvimento sustentável ficarão restritas à elite e o seu processo de difusão não será capaz de modificar, efetivamente, a nossa realidade (FUNDAÇÃO BRASILEIRA PARA O DESENVOLVIMENTO SUSTENTÁVEL, 200-)

\section{3 - Turismo e Desenvolvimento Sustentável}

A OMT apresenta a seguinte definição para o Turismo Sustentável:

"O desenvolvimento do turismo sustentável atende às necessidades dos turistas de hoje e das regiões receptoras, ao mesmo tempo em que protege e amplia as oportunidades para o futuro. É visto como um condutor ao gerenciamento de todos os recursos, de tal forma que as necessidades econômicas, sociais e estéticas possam ser satisfeitas sem desprezar a manutenção da integridade cultural, dos processos ecológicos essenciais, da diversidade biológica e dos sistemas que garantem a vida" (ORGANIZAÇÃO MUNDIAL DO TURISMO, 2003, p.24). 
Percebe-se, a partir da definição acima, que a abordagem do desenvolvimento sustentável é de especial importância para o turismo, já que este depende quase integralmente dos atrativos turísticos e das atividades que estejam relacionadas ao ambiente natural e ao patrimônio histórico e cultural de uma região.

Mas o que se constata na realidade atual é que, da forma como a atividade turística é desenvolvida atualmente, "guiada pela oferta e dominada pelos intermediários" (BURNS, 2002, p.141), não exerce a sustentabilidade.

A maneira como se apresenta o turismo em certos destinos acaba por marginalizar possíveis participantes do processo como integrantes da população de baixa renda ou de áreas rurais da região. Isto pode até permitir um crescimento no sentido econômico, mas relega a segundo plano o desenvolvimento, principalmente no âmbito social.

Não se pode negar a questão da submissão e da descaracterização dos lugares utilizados como destinos receptivos que acabam por se submeter às elites locais e empresas multinacionais.

A partir daí, não podemos deixar de observar que o turismo gera conseqüências, às vezes irreversíveis, sobre a forma como a história de um determinado local é transmitida, sobre o patrimônio cultural ali existente.

Paloucci (2000, apud BEZERRA, 2003, p.32) apresenta quatro desafios a se contemplar quando se trata do conceito de sustentabilidade no turismo:

- uma compreensão melhor de como os turistas avaliam e usam os ambientes naturais;

- aumento e impactos da dependência de comunidades em relação ao turismo;

- identificação dos impactos sociais e ambientais do turismo;

- a implementação de sistemas para administrar estes impactos.

Considerando como referência a oferta, Andrade (2002, p.112), ressalta que para uma reflexão madura não se pode deixar de considerar a seguinte afirmativa: "Todo potencial natural e artificial deve ser conservado e preservado em 
suas finalidades. Sua manutenção cuidadosa e prudente é garantia de aumento e de valorização do patrimônio cultural e da memória".

Bem como outras atividades de visão econômica, o desenvolvimento do turismo deve primar pelo uso não predatório dos bens, sejam eles naturais, culturais ou históricos, através do desenvolvimento planejado de maneira coerente.

Ao mesmo tempo em que gera empregos e movimenta recursos, a atividade turística é um aliado em potencial para a gestão desses bens, já que são elementos formadores do produto turístico e seu uso sustentável fortalece a própria atividade. Faz com que os bens naturais e culturais se tornem atrativos e objeto do fenômeno, sem desgastes sistemáticos ou consumação total através dos meios e recursos que utiliza. Resulta na valorização dos recursos naturais e artificiais e dos equipamentos à disposição (ANDRADE, 2002).

Observamos, então, a denominada sustentabilidade cultural, ou seja,

"a necessidade de se buscar soluções de âmbito local, utilizando-se as potencialidades das culturas específicas, considerando a identidade cultural e o modo de vida local, assim como a participação da população local nos processos decisórios e na formulação e gestão de programas e planos de desenvolvimento turístico" (BEZERRA, 2003, p.110).

A formulação de políticas públicas e de um planejamento criterioso pode contribuir bastante para minimizar ou até mesmo eliminar os efeitos negativos do turismo. O plano de desenvolvimento constitui $\mathrm{o}$ instrumento fundamental na determinação e seleção das prioridades para a evolução harmoniosa da atividade. É importante para assegurar a perpetuação da personalidade coletiva da região em questão (ARCHER E COOPER, 199-).

"As políticas públicas devem ser utilizadas para que a atividade turística venha a ser planejada de forma coerente e eficaz, quando se diz respeito à busca do desenvolvimento local sustentável a partir da mesma" (BEZERRA, 2003, p.03). Deve representar um equilíbrio aceitável entre necessidades atuais e futuras, garantindo que o consumo do turismo não vá exceder a capacidade de um destino anfitrião. 
Para que esse planejamento seja eficiente é necessário que se defina cautelosamente as responsabilidades a serem assumidas pelo setor público, bem como as que caberão ao setor privado.

Isso tudo deve ser efetivado buscando a maximização dos benefícios econômicos em congruência com a mitigação ou até mesmo eliminação de malefícios. Para tanto, não só os setores acima mencionados devem mobilizar-se: a preservação deve ser tomada por todos e não percebida como algo importante apenas no momento em que é responsabilidade de outros.

É preciso também reconhecer que o turismo ocorre em muitos contextos sociais e políticos diferentes e o que dá certo num lugar pode precisar se adaptar para uma região distinta.

A sustentabilidade nem sempre foi prioridade no turismo, principalmente se comparada com a visão de lucro em curto prazo. O desenvolvimento da atividade era ditado pelos interesses dos turistas, empreendedores, planejadores. Com o crescimento do ambientalismo, o pensamento de que os custos sociais e ambientais não eram compensados pelos benefícios econômicos atingiu o turismo e, a partir de então, desenvolvimento sustentável e consumo responsável passaram a fazer parte do planejamento da atividade.

\begin{abstract}
"Portanto, é através da consolidação das políticas de turismo numa localidade que o setor passará a ser tratado de forma organizada e dinâmica, onde o planejamento passe a ser coeso, levando-se em consideração a realidade e as características próprias de casa região, construindo, desta forma, os fatores relevantes e imprescindíveis para que seja possível desenvolver a localidade a partir do turismo" (BEZERRA, 2003, p.04-05).
\end{abstract}

Mais do que isso, é necessário que as barreiras ao planejamento e ao gerenciamento, que se erguem em muitas áreas sejam retiradas para permitir a aplicação eficaz das técnicas existentes (ARCHER E COOPER, 199-). 


\section{PATRIMÔNIO}

\subsection{Patrimônio Material/Cultural.}

O conceito de patrimônio é bastante abrangente, envolvendo aspectos dos mais diversificados. Para ilustrar essa afirmativa, transcreve-se a abordagem de Fonseca (1997, p.49):

"A questão do patrimônio se situa numa encruzilhada que envolve tanto o papel da memória e da tradição na construção de identidades coletivas, quanto os recursos que têm recorrido os Estados modernos na objetivação e legitimação da idéia de nação [...]. Nesse sentido, os bens que constituem os patrimônios culturais se propõem como marcas do tempo no espaço".

Para Coelho (1992, p.31), Patrimônio "é todo o meio ambiente criado pelo homem".

Olínio Coelho (1992) destaca, ainda, que o patrimônio cultural envolve não só todas as realizações do homem, como também o meio em que vive e os recursos apresentados pela natureza e que são por ele transformados para prover suas necessidades materiais e espirituais.

O interesse da sociedade sobre um determinado bem é um dos principais motivos para que este seja considerado patrimônio. Juridicamente falando, no Brasil um bem é reconhecido como patrimônio pelo valor cultural a ele atribuído, "quer por sua vinculação a fator memorável da história do Brasil, quer por seu excepcional valor arqueológico ou etnográfico, bibliográfico ou artístico" (Artigo $1^{\circ}$ do Decreto-lei $\mathrm{n}^{\circ} 25$, de 30.11.37, apud FONSECA, 1997, p. 34).

Ainda sobre esse aspecto, a Constituição Federal de 1988, descreve em seu artigo 216:

"Art. 216. Constituem patrimônio cultural brasileiro os bens da natureza material e imaterial, tombados individualmente ou em conjunto, portadores de referência à identidade, à nação, à memória dos diferentes grupos formadores da sociedade brasileira, nos quais se incluem: 
I - as formas de expressão;

II - os modos de criar, fazer e viver;

III - as criações científicas, artísticas e tecnológicas;

IV - as obras, objetos, documentos, edificações e demais espaços destinados às manifestações artístico-culturais;

$\mathrm{V}$ - os conjuntos urbanos e sítios de valor histórico, paisagístico, artístico, arqueológico, paleontológico, ecológico e científico" (BRASIL, 2005, p. 138 -139).

Esses bens incluem tudo aquilo que diz respeito à construção espacial e às demais formas de valores artísticos, expressas por meio da arte, da música, da dança, dentre outras manifestações.

A preservação se faz necessária por tudo o que esse bem tenha representado ou represente para a sociedade, seja ele natural ou produzido pelas mãos do homem, tais como fatores históricos, artísticos, arqueológicos, etnográficos, bibliográficos, toda e qualquer expressão relevante de uma época ou de um acontecimento, que seja de grande valor comum para a sociedade da qual ele faz parte. "O histórico e o artístico assumem, nesse caso, uma dimensão instrumental, e passam a ser utilizados na construção de uma representação de nação" (FONSECA, 1997, p. 31).

Segundo Barretto (2000, p. 14), a maneira legal para se realizar essa preservação é o tombamento, o qual

"... consiste num registro do bem num "livro de tombo", em cujas páginas ficam registrados os bens considerados valiosos e sujeitos às leis de preservação do patrimônio, o que implica não poderem ser demolidos nem modificados em seu aspecto externo ou em suas características essenciais, implicando também que, num raio de 300 metros nada pode ser modificado".

A caracterização de "bem" é dotada de alguns critérios segundo os quais os bens culturais se subdividem entre monumentos, bens móveis e sítios (FONSECA, 1997).

Os monumentos são os bens isolados de valor histórico, artístico e arqueológico. Podem ser percebidos como partes integrantes dos sítios. São exemplares de arquitetura civil, religiosa, militar, construções comemorativas, fragmentos ou até mesmo ruínas representativas desses exemplares. 
Os bens móveis se constituem de criações do homem, de suas realizações espirituais. É uma parcela de expressão da cultura de um grupo. Aqui se inclui o artesanato, os folguedos, as obras literárias, documentos que representam o aspecto regional da localidade, lendas, cantos, fazeres e saberes de um povo.

Os sítios são conjuntos em que se percebe um valor agregado sobre as criações de autoria do homem ou criadas pela natureza. De acordo com seu "conteúdo", esses conjuntos podem ser denominados sítios naturais (também denominados de parques naturais), sítios históricos, sítios científicos, sítios urbanos e ainda, sítios mistos - "aqueles sítios naturais marcados pela presença e pela criação do homem" (COELHO, 1992, p. 32).

A ONU define o Patrimônio Cultural no artigo $1^{\circ}$ de sua Convenção sobre a Proteção do Patrimônio Mundial Cultural e Natural (Paris, 17 de outubro a 21 de novembro de 1972), onde registra:

"Artigo $1^{\circ}$ - Para os fins da presente Convenção são considerados 'patrimônio cultural':

Os monumentos: obras arquitetônicas, esculturas ou pinturas monumentais, objetos ou estruturas arqueológicas, inscrições, grutas e conjuntos de valor universal excepcional do ponto de vista da história, da arte ou da ciência;

Os conjuntos: grupos de construções isoladas ou reunidas, que, por sua arquitetura, unidade ou integração à paisagem, têm um valor universal excepcional do ponto de vista da história, da arte ou da ciência;

Os sítios: obras do homem ou obras conjugadas do homem e da natureza assim como áreas, incluindo os sítios arqueológicos, de valor universal excepcional do ponto de vista histórico, estético, etnológico ou antropológico."

Considerando o turismo com relação ao patrimônio cultural, devemos entender que esta atividade efetivamente se realiza baseada no acervo cultural que inclui na natureza que o homem protege outras formas para a satisfação de suas necessidades materiais e espirituais (COELHO, 1992, p. 54). 
A atividade turística é um grande estímulo para a manutenção da existência e a reabilitação de sítios históricos, propiciando a revitalização de atividades e áreas tradicionais.

\section{2 - Patrimônio Cultural, Turismo e Desenvolvimento}

Fruto da sociedade moderna e sua conotação características, o turismo busca a diferença para vender necessidades, a necessidade de consumo de lazer e turismo. É produto da sociedade capitalista industrial e se desenvolveu sob o impulso de motivações diversas, que incluem o consumo de bens culturais (CORIOLANO, 1998).

O Patrimônio Cultural representa o passado de uma nação, de um povo, de uma comunidade. Mas para que ele tenha algum significado para a localidade onde está inserido, a consonância entre três elementos são indispensáveis: a comunidade, a iniciativa privada e o poder público (BEZERRA, 2003).

Os Sítios Históricos apresentam relevante valor para o desenvolvimento local, pois são fatores de promoção da cidade, um recurso para estimular o desenvolvimento. O que deve se observar, entretanto, é que este é um recurso não renovável (AZEVEDO, 2006b).

O patrimônio cultural de uma sociedade é muito diversificado e sofre alterações permanentemente, decorrentes das mudanças de usos e costumes, que evoluem lentamente com o passar do tempo, sendo sua existência de vital importância para uma sociedade, pois funciona como um referencial e como identidade de um povo (BATISTA, 1999).

O Turismo Cultural, hoje em dia, implica não apenas a oferta de espetáculos ou eventos, mas também a existência e preservação de um patrimônio cultural representado por museus, monumentos e locais históricos, um patrimônio turístico, que pode ser entendido como "um conjunto de bens naturais e culturais 
que, por suas características instrísecas, possuem atratividade para visitação" (CORIOLANO, 1998, p. 217).

A comunidade deve se conscientizar da importância desse patrimônio que é seu. A iniciativa privada pode ajudar nesse processo de conscientização e resgate, investindo em projetos de sensibilização. Ao Poder Público cabe o dever de valorizar os bens patrimoniais, inclusive usando-os como mercadorias culturais, através da atividade turística, além de reintegrá-lo à sociedade, pois o desenvolvimento do turismo provoca o desenvolvimento de diversos setores conexos em função do efeito multiplicador do investimento (BEZERRA, 2003).

O dever de proteger o patrimônio é do Estado, mas em caráter suplementar. Os proprietários de bens, e a comunidade como um todo devem assumir sua responsabilidade (AZEVEDO, 2006b).

A falta de consciência para a importância da preservação, segundo Coriolano (1998, p.217), seria, a rigor, um dos diversos ângulos norteadores da questão do patrimônio cultural em nosso país. Como conseqüência dessa falta de consciência é possível observar perda de grande parte do patrimônio histórico construído pelo homem durante sua evolução.

"A riqueza patrimonial arquitetônica e cultural existente [....] é repleta de significados e sentidos, porém não são totalmente percebidos por parte da população. Isso se deve ao descaso por parte do Poder Público e à descrença da população em suas raízes. No entanto, tais elementos, como arquitetura, culinária, manifestações culturais e folclóricas devem ser revitalizados como produto turístico". (BEZERRA, 2003, p.108).

Essa proteção fortalece a herança cultural e histórica da localidade. Para potencializá-la como produto turístico, no entanto, é preciso respeitar as necessidades e os direitos da comunidade.

\footnotetext{
"Essa visão, mais responsável e consciente com a própria natureza da atividade turística, incorpora na relação homem versus natureza, turismo versus turismo, uma sintonia necessária para o aproveitamento dessa atividade, tomando o visitante atual um parceiro para o desenvolvimento turístico da localidade". (BEZERRA, 2003, p. 09).
} 
O patrimônio aparece na estratégia de desenvolvimento local, mas esta, por seu turno, não está amplamente disseminada entre os diferentes atores. Para que isso ocorra é necessário considerar o patrimônio como um recurso para o desenvolvimento, pois este é um conjunto de bens de vida própria e de um regime de interação com a sociedade e, na realidade, os sítios históricos, em geral, têm sido tratados de forma isolada no contexto da cidade (AZEVEDO, 2006a).

É bem verdade que em algumas localidades essa proteção acontece de forma natural, mas é importante ressaltar que, nesses casos, o patrimônio está inserido no cotidiano local. "Infelizmente o ato de preservar o patrimônio cultural ainda é visto como uma tarefa de alguns, relegada àqueles que a exercem quase como uma prática sacerdotal, de sacrifícios e abnegações" (BRITO, 2004a, p. 30).

Plog (1994, p. $52-53$ apud BURNS, 2002, p. 142-143) propõe uma abordagem idealista para a formação de novas parcerias entre o global e o local, reconhecendo, pelo menos, a existência de um problema. Para tanto explica que o natural e o histórico devem ser restaurados, retendo o senso de patrimônio, continuidade e comunidade. A cultura e as tradições locais precisam ser valorizadas buscando a proteção das populações locais e seu patrimônio. Deve-se obter a aceitação da comunidade, de modo que as populações sejam as beneficiadas com o turismo em parceria com os empreendimentos comerciais.

Por sua própria natureza, o turismo é seduzido por ambientes e sociedades singulares e frágeis, representa um dos veículos mais importantes de divulgação cultural. Em alguns casos é bastante evidente que os benefícios econômicos são superados pelas conseqüências ambientais e sociais produzidas.

Fica evidente, então, a importância da gestão compartilhada, da formulação de um plano de preservação. A gestão compartilhada apresenta condicionantes como a escassez de recursos, a dispersão de iniciativas, o desnivelamento de conhecimento entre as partes e a existência de processos não sustentáveis, onde muitas das vezes as comunidades são exiladas disfarçadamente do contexto. 
Quanto ao plano de preservação, se descreve como Instrumento Setorial de Gestão Urbana Compartilhada, baseado na compatibilização de demandas de desenvolvimento urbano associados aos aspectos da Preservação do Patrimônio Cultural existente na localidade (AZEVEDO, 2006).

O que se busca com isso é que as cidades históricas resgatem suas características essenciais de identificação, mas sem deixar por conta disso de absorver as novas linhas da modernidade, da dinâmica das relações sociais. Resgatar e adequar o patrimônio cultural aos processos urbano e socioeconômico vigentes, buscando sempre a ação compartilhada no processo de preservação.

Um conceito importante para a aceitação e aplicação da preservação conjunta é a idéia de urbs, que propõe a visão das cidades como lugares vivos e visa reintegrá-las à dinâmica do desenvolvimento local (BRITO, 2004).

Ainda segundo Brito (2004, p. 22), “desse entendimento surgem as ações que, ao longo das últimas décadas do século passado, têm norteado processos de preservação, pautados na recuperação e na revitalização de áreas históricas degradadas, deterioradas fisicamente, marginalizadas socialmente e deprimidas economicamente".

O autor destaca ainda que a preservação passa então a ser vista também como uma forma de desenvolvimento, um desenvolvimento que se expresse de modo ecologicamente equilibrado e culturalmente diversificado.

"Assim, entender hoje as cidades históricas como urbs implica em considerar as suas estruturas físicas, heranças legadas pelos nossos antepassados, o corpo do ser vivo existente, mas também as suas estruturas sociais, que lhes dão significado, vida própria, movimento, a alma do ser vivo pulsante. Corpo e Alma do patrimônio cultural urbano, ser integral". (BRITO, 2004, p. 23).

O patrimônio histórico-cultural deve ser visto, inicialmente, como uma ferramenta para o bem estar da população residente. Decidir sobre a sua utilização para fins turísticos cabe à própria comunidade local. 


\section{4 - CENTRO HISTÓRICO DE SÃO LUÍS/MA - A ÁREA DA PRAIA GRANDE}

\subsection{Aspectos Históricos.}

A capital do Estado do Maranhão, São Luís, está localizada a $2^{\circ} 27^{\prime}$ latitude Sul e a $46^{\circ} 29^{\prime}$ longitude Oeste, na margem Ocidental da ilha do mesmo nome, na confluência dos estuários dos rios Anil e Bacanga. É banhada ao Norte e Oeste pela Baía de São Marcos e a Leste e Sul pelas Baías de São José e do Arraial respectivamente. A ilha tem $905 \mathrm{~km}^{2}$, dos quais $518 \mathrm{~km}^{2}$ correspondem ao município de São Luís.

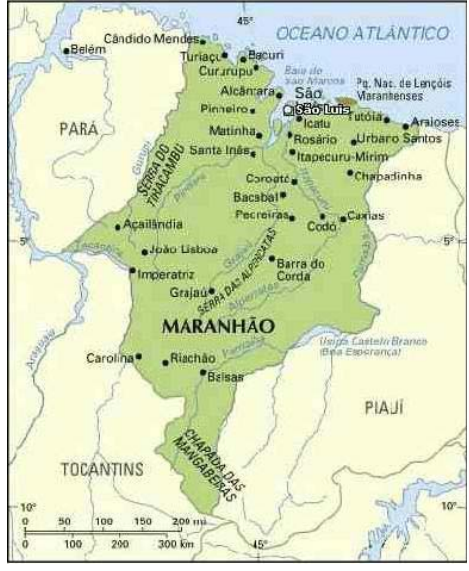

Figura 1. Mapa de Localização do Maranhão. Fonte: VOU DE MOCHILA, 2007

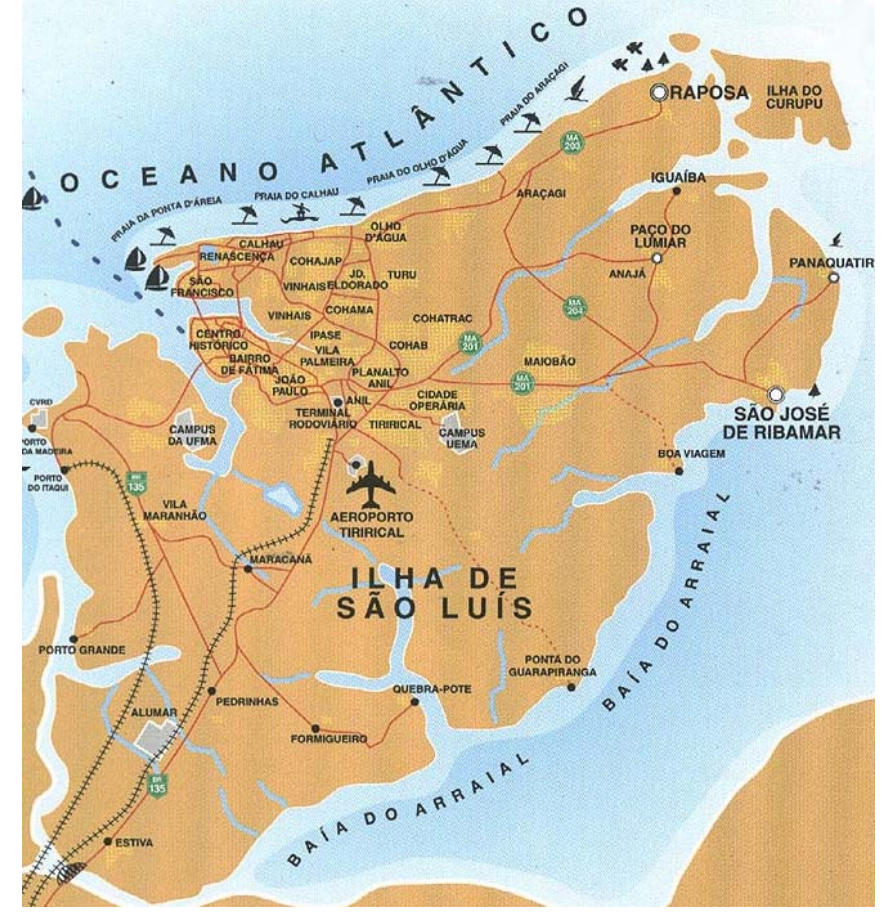

Figura 2. Mapa de Localização de São Luís. Fonte: VOU DE MOCHILA, 2007 
Em 1535, com a divisão do Brasil em capitanias hereditárias pelo rei João III de Portugal, o tesoureiro e historiador João de Barros foi convocado para a missão de colonizar a Capitania do Maranhão, localizada no extremo norte do país.

Mais de três mil colonos, divididos em quatro frotas, desembarcaram na então denominada cidade de Nazaré, provavelmente situada onde hoje é a cidade de São Luís, na primeira tentativa de que se tem registro de colonização do local.

As dificuldades náuticas e o descaso das autoridades com a região fizeram com que esta fosse abandonada, impedindo seu desenvolvimento, ao contrário de outras regiões do país, como Olinda/PE e Salvador/BA (MARTINS, 1999).

O espaço deixado pelos portugueses facilitou o contato de outros exploradores europeus, que estabeleceram comércio com os indígenas habitantes da área e acumularam informações. De posse desses conhecimentos, os franceses logo demonstraram grande interesse em fundar aqui sua França Equinocial. Um projeto ambicioso, que propunha a tomada da região, principalmente por conta do interesse dos grandes rivais portugueses, mas também pelas vantagens percebidas em expedições anteriores (MEIRELES, 2001).

Segundo Meireles (2001, p. 40), Daniel de la Touche, fidalgo, Senhor de la Ravardière, teve concessão de Maria de Médice, regente da Coroa francesa durante a menoridade de Luís XIII, "para estabelecer uma colônia ao sul da Equinocial com extensão de 50 léguas para cada lado do forte que aí erigisse". Associou-se a outros fidalgos e organizaram a expedição com cerca de 500 homens distribuídos em três navios: a nau Regente, capitânia, sob o comando do próprio almirante de Razilly e em que vinha também La Ravardière; a nau Charlotte, sob o comando do Barão de Sancy, e o patacho Saint'Anne, sob o comando de Claude de Razilly, Barão de Launay. Vinham também os primeiros missionários católicos, quatro capuchinhos do Convento de Saint'Honoré, em Paris: Yves d'Evreux, como superior, Claude d'Abbeville, Arsène de Paris e Ambroisse d'Amiens.

Após extensa viagem, aos oito dias do mês de setembro de 1612, a expedição francesa, sob o comando de Daniel de la Touche, funda a Vila de São 
Luís, nomenclatura em homenagem ao jovem rei da França Luís XIII.O marco da fundação foi o Forte São Luís, onde hoje se localiza o Palácio dos Leões, localizado no promontório formado pelos Rios Bacanga e Anil, na Baía de São Marcos, forte esse que foi construído pelos franceses e indígenas. Logo os franceses iniciaram suas ações de catequese, de consolidação da relação com os nativos, intervindo sempre contra os portugueses.

O Maranhão já era um Estado, detentor de capitanias e novamente sob domínio lusitano quando aqui chegaram dois mil holandeses, vindos de Pernambuco em 18 navios comandados por Jan Cornelizoon Lichtard, que aqui permaneceram de 1641 a 1644, quando foram expulsos por Antônio Teixeira de Melo, após sucessivos combates que culminaram na fuga dos invasores para Pernambuco (MEIRELES, 2001)

No final do século XVII a Coroa decidiu adotar providências mais efetivas que trouxessem desenvolvimento para a região, com a finalidade de garantir sua posse, implantando o Palácio do Estado, criando uma diocese para o Maranhão, construindo o Palácio do Município e a Catedral, trazendo o primeiro bispo, fazendo "um esforço para manter São Luís em contato direto com o centro do Império, criando uma imagem de capital rica em obras de arte, que constituem um acervo artístico da mais alta qualidade" (ANDRÉS, 1998, p. 22).

Outro fator de grande importância foi a criação da Companhia do Comércio do Grão Pará e Maranhão, que proporcionou grandes melhorias na economia do Estado. São Luís se tornou um dos principais pólos de um corredor de comércio e exportação de algodão e arroz. Em um intervalo de duas décadas, a transformação econômica efetivada pela Companhia ensejou o surgimento do Centro Histórico da cidade. Em 1850, é considerada a quarta cidade mais importante do Império, antecedida por Rio de Janeiro, Salvador e Recife.

A fase de inovações e evoluções atinge o século $X X$, quando São Luís se tornou a primeira cidade do Norte e Nordeste a ser dotada de sistema de bondes, de iluminação pública e de gás conduzido por via subterrânea, época em que começaram a funcionar a Companhia de Águas e a Companhia Telefônica (ANDRÉS, 1998). 
Esse desenvolvimento deu-se, principalmente, na área onde se concentravam as atividades financeiras, econômicas, mercantis e portuárias, um conjunto homogêneo de 220 hectares, com destaque para os bairros da Praia Grande, Desterro e Ribeirão (PEREIRA, 1994)

A parte urbanizada se limitava, praticamente, ao Centro Histórico. E ali estão os maiores vestígios da estagnação econômica pela qual São Luís passou na década de 20, quando foi possível observar a redução das atividades e de suas funções. São edificações que, por conta da estagnação, mantiveram suas características do período colonial intactas, e até hoje colaboram para a beleza do Patrimônio Cultural da capital ludovicense.

A Praia Grande, hoje um dos mais singulares e representativos bairros de São Luís, está situada exatamente entre as embocaduras dos rios Anil e Bacanga, na parte baixa da cidade. Eram chamadas praias as margens desses rios. No Anil encontrávamos a Praia Pequena, a Praia do Caju e a de Santo Antonio. Às margens do rio Bacanga localizavam-se as mais notórias, as Praias da Madre Deus e a Praia Grande, hoje região onde se encontra o bairro homônimo.

Martins (1999, p. 67) descreve que a Praia Grande era formada por uma curva para dentro que fazia logo abaixo do forte, local marco de fundação da cidade de São Luís, atual Palácio dos Leões. Esse formato côncavo, essa reentrância, constituía uma posição estratégica, fato este que lhe permitiu ser o principal porto de carga e descarga de mercadorias desde o século XVII.

Foi a área preferida dos abastados comerciantes para construírem suas residências e instalarem seus armazéns de secos e molhados, durante os séculos XVIII e XIX, e também na primeira metade do século $X X$, pela sua imediata proximidade com o porto, pois todo o comércio era feito pelas vias marítima e fluvial (VAGALUME, 1993).

Em seus primórdios, havia ali uma área de pântanos e manguezais onde se estabeleceu o "centro comercial", o local de encontro da oferta e demanda da São Luís daquela época, "com considerável significação para a vida da população ludovicense em tempos idos" (VAGALUME, 1993, p. 11). 
A região passou por transformações, evoluções e, de maneira rudimentar e desorganizada, foi dando origem ao que hoje conhecemos por Casa das Tulhas, mais conhecida como Feira da Praia Grande. Ali de tudo se vendia, "com exceção de carne de gado vacum, que só podia ser vendida no Açougue Velho, próximo ao Portinho" (MEIRELES \& TEIXEIRA, 1979, p. 05).

Peixes, mariscos, frutas, legumes, aves, animais vivos ou abatidos, farinha, entre outros produtos, eram oferecidos. Com o crescimento, surgiu a necessidade de melhorias no local. Percebendo isto, em 1740, Dom Diogo de Souza realiza pequenas obras para possibilitar a armazenagem e comercialização de gêneros de forma mais cômoda (VAGALUME, 1993).

Em 1780, a corte de Lisboa expressa a vontade de ali edificar uma praça regular. Solicita ao governo da Província um detalhamento da área com a pretensão de efetivar esse anseio. Surgem, então, no lugar dos mangues e pântanos, sobrados com partes em cantaria e azulejos de revestimento, "era o embrião e o centro arquitetônico da cidade de São Luís, seu coração e ao mesmo tempo seu centro nervoso" (VAGALUME, 1993, p. 11-12).

Atualmente, envolve um conjunto de edificações, formando um quadrilátero que pelo seu volume é considerado de elevado grau monumental e mérito arquitetônico, onde hoje funciona o Mercado da Praia Grande, que além de secos e molhados (aves, camarão, peixe seco, farinha d'água, fumo de corda, mel de abelha, tiquira e outros diversos produtos e utensílios domésticos, produzidos tanto em São Luís como no interior do Estado, caracterizadores da nossa cultura), comercializa artesanato e é local de grande procura pelos turistas.

Com o aterro do lodaçal, a construção do cais, a pavimentação das ruas, a edificação da Casa da Praia Grande, surgiu o pequeno bairro que se formou sobre o primitivo manguezal que fora chamada Praça da Praia Grande, onde aos poucos se foram levantando os sobradões solarengos, muitos deles de coruscantes fachadas de azulejos e de portas e janelas rasgadas em moldura de cantaria, que hoje enobrecem e orgulham a cidade e constituem invejável patrimônio histórico e 
arquitetônico que já se transforma em valiosa atração turística (MEIRELES \& TEIXEIRA, 1979, p. 07).

O Bairro da Praia Grande causa ainda, a todos que hoje o contemplam, certo impacto pela suntuosidade dos casarões e sobrados azulejados, instalados sobre passeios de cantaria portuguesa (pedras brancas enormes trazidas como lastro nos porões dos navios mercantes das frotas lusitanas), conferindo-lhes beleza singular, com suas sacadas de ferro, atestado de uma fase de prosperidade econômica e requintado bom gosto.

Também se encontra na Praia Grande o Museu de Artes Visuais, um sobradão em azulejo português que abriga obras de pintores e escultores maranhenses, com magnífica coleção de gravuras de Arthur Azevedo.

O Beco Catarina Mina é uma pequena rua formada em grande parte por uma escadaria com 35 largos degraus em pedra de cantaria, limitada nos extremos por sobrados coloniais. Sua denominação se deve à bela negra Catarina Rosa de Jesus, moradora de um de seus sobrados, que enriqueceu e se fez proprietária de imóveis e senhora de escravos, tomando ares de grande dama.

Na Praia Grande também estão instalados, em belos sobrados, o Arquivo Público, o Centro de Criatividade Odylo Costa Filho, o Centro de Cultura Popular Domingos Vieira Filho, a Câmara Municipal de São Luís, além de vários órgãos públicos estaduais, bem como bares, restaurantes, lanchonetes e algumas poucas e tradicionais casas comerciais remanescentes do apogeu econômico do Maranhão.

Nesse perímetro está também o Cais da Sagração, onde costumavam ancorar os navios antigos; o Palácio dos Leões, local onde até 1615 funcionava o Forte que protegia a capital da França Equinocial; a Catedral da Sé, construída pelos Jesuítas em 1726; a Igreja do Carmo, construída em 1627, uma das mais antigas da cidade; o Teatro Arthur Azevedo, construído entre 1815 e 1817, o primeiro a ser edificado em uma capital de estado brasileiro, e a Fonte do Ribeirão (1796), que possui três portões de ferro dando acesso a passagens que servem para escoamento de águas subterrâneas pluviais e para fertilizar a fantasia de muitos que lhe atribuem diversas lendas (MARTINS, 1999). 
É, portanto, um local onde se encontram importantes atrações turísticas da cidade. O bairro, quase todo restaurado pelo Projeto Reviver (principal projeto de revitalização da área da Praia Grande, inaugurado em 1989), é ponto cultural de destaque na ilha. Trata-se de um dos locais mais importantes da cidade pelo olhar do turismo e pelo seu valor histórico-cultural.

\section{2 - O Patrimônio Cultural na Praia Grande}

Com o objetivo de incentivar a preservação de bens culturais e naturais de significação considerada extraordinária para a humanidade, foi criada a Convenção do Patrimônio Mundial (WORLD HERITAGE COMMITTEE), no ano de 1972, pela UNESCO.

A Convenção tem como foco basal a eleição de áreas naturais ou culturais expressivas, existentes em cada país ou região elevado à categoria de Patrimônio Mundial, ampliando a importância e buscando a preservação das mesmas.

Para Bosque Morel (1999, p. 78-79), "a criação desta categoria não é nem mais nem menos que mais um capítulo, um dos primeiros na nossa história de globalização". Essa globalização que Avighi (2000, p.13) define como "um aparato da tecnologia da comunicação que enlaça as atividades econômicas do mundo industrializado e que propicia uma nova interação simbólica das pessoas".

Um processo que também pode provocar ameaças, ainda mais somado à realidade capitalista de nossa atualidade.

Nesse sentido, Guedes (2001, p. 27), salienta que:

"Na busca pela dominação, o capitalismo gera um fenômeno interessante, ao mesmo tempo que a globalização incentiva a quebra das fronteiras, posicionado-se contrariamente à diversidade que notoriamente existe no mundo, paradoxalmente a isto, há um reforço nas diferenciações culturais incentivadas pela preservação oriundas dos processos de patrimonialização 
que buscam as suas raízes como forma de não perder o referencial ora ameaçado pelo processo da globalização".

A UNESCO percebe a globalização sob seu aspecto positivo e expressa isso quando se posiciona afirmando que o conceito de Patrimônio Mundial se torna excepcional pela sua aplicação universal. Os sítios do Patrimônio Mundial pertencem a todos os povos do mundo, independentemente do território em que estejam localizados.

Para a instituição, a Convenção do Patrimônio Mundial se tornou um instrumento de paz e de unidade para todos os povos da Terra. O Comitê do Patrimônio Mundial, constituído por 21 representantes dos Estados-Parte da Convenção, responsável por guiar a implementação da Convenção do Patrimônio Mundial, tem como objetivos fundamentais os seguintes (BOSQUE MOREL,1999):

1 - identificar e anunciar aqueles lugares de interesse natural e cultural que devem ser protegidos pela Convenção do Patrimônio Mundial, inscrevendo-os na Lista do Patrimônio Mundial;

2 - difundir por todo o mundo a existência desse patrimônio e procurar despertar na opinião pública a consciência de sua responsabilidade, respeito à proteção de cada um dos bens que constituem a lista; e

3 - proporcionar ajuda técnica aos componentes do Patrimônio Mundial, de todos os modos possíveis, àqueles bens, quando os recursos dos países aos quais esses bens são ligados forem insuficientes.

Quanto à preservação dos bens tombados, é de responsabilidade do país onde se localizam, ficando a cargo da UNESCO o apoio técnico e financeiro com recursos do Fundo do Patrimônio Mundial.

É preciso ter a consciência de que a inscrição na lista do Patrimônio Mundial é bem mais que um prêmio: é um compromisso a ser assumido. Essas áreas devem passar a ser paradigmas de modo de conservação e utilização para todo o patrimônio. E para assumir e cumprir esse compromisso é necessário bem mais que investimentos financeiros: é preciso capital intelectual, conhecimento e informação (UNESCO, 2002). 
Por conta disso, a UNESCO se une a entidades como o ICOMOS, fundado em 1965 - ao qual Bosque Morel se refere da seguinte maneira:

\begin{abstract}
"Esta é uma das associações profissionais mais capacitadas e melhor preparadas para recuperar o conhecimento e a informação suficiente sobre a realidade monumental, em cada uma das partes, em cada uma das nações que compõe o mundo em que vivemos". (BOSQUE MOREL, 1999, p.81).
\end{abstract}

A Praia Grande foi alvo dos estudos do ICOMOS durante o processo de inclusão do Centro Histórico de São Luís na Lista do Patrimônio Mundial, na categoria de Patrimônio Cultural.

A maioria dos sobrados existentes na Praia Grande, cujas edificações datam da época do "boom" econômico maranhense, possuem características totalmente influenciadas pela arquitetura portuguesa, desde a época do Brasil Colonial, sendo a maioria composta de três pavimentos (ANDRÉS, 1998).

São casarões em forma de "L" ou de "U", onde se destacam as estratégias de adaptação ao clima local, como os pés direitos altos, com mais de quatro metros de altura; as venezianas nas varandas internas em direção ao pátio central e os azulejos revestindo a face externa da casa. Talvez seja essa a característica de maior relevância simbólica, pois se tornou ícone muito forte na imagem da cidade. Esses pequenos azulejos, em sua maioria portugueses, mas também vindos de outras partes da Europa, como Espanha e França, não tinham apenas função estética nas fachadas (ANDRÉS, 1998).

Eram eles responsáveis pela proteção do imóvel nos períodos das chuvas fortes e, durante o verão de intenso calor, refletiam os raios solares amenizando a temperatura no interior da construção. São Luís se torna la petit ville aux palais de porcelaine ${ }^{1}$ (ANDRÉS, 1998).

Como conseqüência, proprietários repetiram o feito em seus bens em Lisboa e na Cidade do Porto. "Pela primeira vez uma invenção artística colonial influenciava a antiga metrópole" (ANDRÉS, 1998, p. 27).

\footnotetext{
1 "A pequena cidade dos palácios de porcelana."
} 
A Praia Grande possui prédios que correspondem a um dos maiores conjuntos arquitetônicos de origem portuguesa, sendo o mais valioso da arquitetura colonial dos séculos XVIII e XIX, prédios estes que se dispõem em um traçado diferenciado das demais cidades coloniais do Brasil e suas ruas estreitas e sinuosas (UNESCO, 2002).

Em São Luís, Francisco Frias de Mesquita - arquiteto, engenheiro militar e Engenheiro-mor do Estado do Brasil - elaborou uma disposição plana, regular e geométrica, estilo mais comum nas colônias espanholas, mais conhecido como "tabuleiro à espanhola" (UNESCO, 2002).

Para a UNESCO, o Patrimônio Cultural é composto por monumentos, grupos de edifícios ou sítios que tenham valor histórico, estético, arqueológico, científico, etnológico ou antropológico (REGO, 1998).

Para tal, foram firmados os seguintes critérios:

1 - possuir obra importante do gênio criativo humano;

2 - testemunho de valor sobre a história da arquitetura, urbanismo ou paisagismo de uma época ou área cultural;

3 - testemunho excepcional de uma tradição cultural de uma civilização;

4 - exemplo importante de conjunto arquitetônico ou paisagístico urbano que ilustra momentos significativos da história da humanidade;

5 - exemplo importante de um assentamento humano tradicional, que é também representativo de uma cultura e de uma época;

6 - bens com vínculos diretos às atividades ou tradições, às idéias, crenças ou obras artísticas e literárias de importante significado universal.

O Centro Histórico de São Luís com seu acervo arquitetônico, foi aprovado com base nos critérios 3 (três), 4 (quatro) e 5 (cinco).

Sobre a aprovação, descreve a UNESCO:

Testemunho excepcional de tradição cultural: se refere à grande preservação do casario colonial no centro histórico da capital maranhense, retrato preservado da presença portuguesa no século XVIII e início do XIX. 


\section{Exemplo destacado de conjunto arquitetônico e paisagem urbana,}

que ilustra um monumento significativo da história da humanidade: o centro histórico de São Luís é considerado a maior área de arquitetura colonial portuguesa existente no Brasil.

Exemplo importante de um assentamento humano tradicional, que também é representativo de uma época: a ausência de modificações ao longo do tempo na área central da cidade preservou um conjunto muito homogêneo, apesar da grande extensão.

"São Luís agora faz parte de uma parcela privilegiada do mundo, com valor universal, reconhecido mundialmente, com este título a capital maranhense está ligada ao restante do mundo por meio deste firme laço cultural" (RÊGO, 1998, p.9).

O processo de inscrição de um bem na Lista do Patrimônio Mundial é desenvolvido em cinco etapas distintas. Em primeiro lugar, o Estado-Parte ao qual o bem em questão pertence prepara uma lista de propriedades que sejam consideradas de "excepcional valor universal". Em seguida, entra em ação o Centro do Patrimônio Mundial, criado em 1992 para assegurar a administração diária da Convenção, também responsável pela administração do Fundo do Patrimônio Mundial e pela atualização da Lista do Patrimônio Mundial, base de dados utilizada para as suas tarefas. Nesse momento do processo o Centro verifica se a solicitação de inclusão está completa (BATISTA, 1999).

No terceiro instante, especialistas são enviados para visitar os sítios, avaliar a sua proteção e gerenciamento. É preparado um relatório técnico e se realiza a avaliação quanto ao "excepcional valor universal".

Para essa tarefa, os órgãos consultivos acionados são as organizações não governamentais (ONG's): ICOMOS, para os bens da categoria Cultural, e o IUCN, quando se tratar de bens naturais (ANDRÉS, 1998).

Continuando, o Bureau do Patrimônio Mundial, órgão executivo formado por sete membros do Comitê do Patrimônio Mundial, examina a avaliação, faz uma recomendação ou solicita informações adicionais para o Estado-Parte (ANDRÉS, 1998). 
Na quinta e última etapa, o Comitê, responsável pela aplicação da Convenção, toma a decisão final de inscrever o sítio na Lista do Patrimônio Mundial ou adia a decisão, aguardando informações mais aprofundadas ou, ainda, recusa a inscrição (ANDRÉS, 1998).

É de 1966 o primeiro registro de visita de representantes da UNESCO com fins de produzir um diagnóstico da área em São Luís, quando por aqui desembarcou $\mathrm{O}$ arquiteto francês Michel Parent. $O$ ato não teve resultado significativo, assim como ocorreria em 1973, na segunda ação que se teve notícia, desta vez sob a direção de Viana de Lima, arquiteto português. Em ambas as oportunidades, a UNESCO enviou arquitetos a pedido do Governo do Estado, para que fosse produzido um conjunto de diretrizes para a preservação de São Luís (BATISTA, 1999).

A caminhada da capital rumo à titulação em questão teve outro importante momento em 1979, quando foi lançado o Projeto Praia Grande, que visava melhorias nos aspectos social, econômico e de infra-estrutura (BATISTA, 1999).

Em seguida, no ano de 1987, outro Projeto de extrema importância foi posto em prática: o Projeto Reviver, "um espaço que se constitui ao mesmo tempo atração turística e fonte de geração de emprego e renda" (BATISTA, 1999, p.91).

Em 1996, o Governo do Estado volta a atuar na busca do reconhecimento da UNESCO e, em maio desse ano, envia um dossiê à Organização. No mês de novembro seguinte, Júlio Angel Morosi desembarca na cidade chefiando uma equipe de arquitetos que fizeram o reconhecimento da área.

O dossiê foi aprovado pelo ICOMOS, bem como o relatório de verificação produzido pela equipe de Morosi, e encaminhado em março de 1997 à UNESCO. Em junho desse mesmo ano, aconteceu a $21^{\text {a }}$ Reunião Internacional do Bureau do Comitê do Patrimônio Mundial, onde a recomendação do Conselho Internacional de Monumentos e Sítios foi aprovada (BATISTA, 1999).

Finalmente, em dezembro de 1997, a Assembléia, durante reunião realizada na cidade de Nápolis - Itália, homologa a decisão técnica do Bureau e, 
então, oficializa a inclusão do Centro Histórico de São Luís como Patrimônio Cultural da Humanidade, sob a seguinte justificativa:

"O comitê decidiu inscrever esta propriedade na base dos critérios (iii), (iv) e (v), considerar que o centro histórico de São Luis do Maranhão é um exemplo proeminente de uma cidade colonial portuguesa que se adaptou com sucesso às condições climáticas da América do Sul equatorial e que preservou seu traçado urbano, integrado harmoniosamente com seu ajuste natural, a um grau excepcional" (UNESCO, 2002).

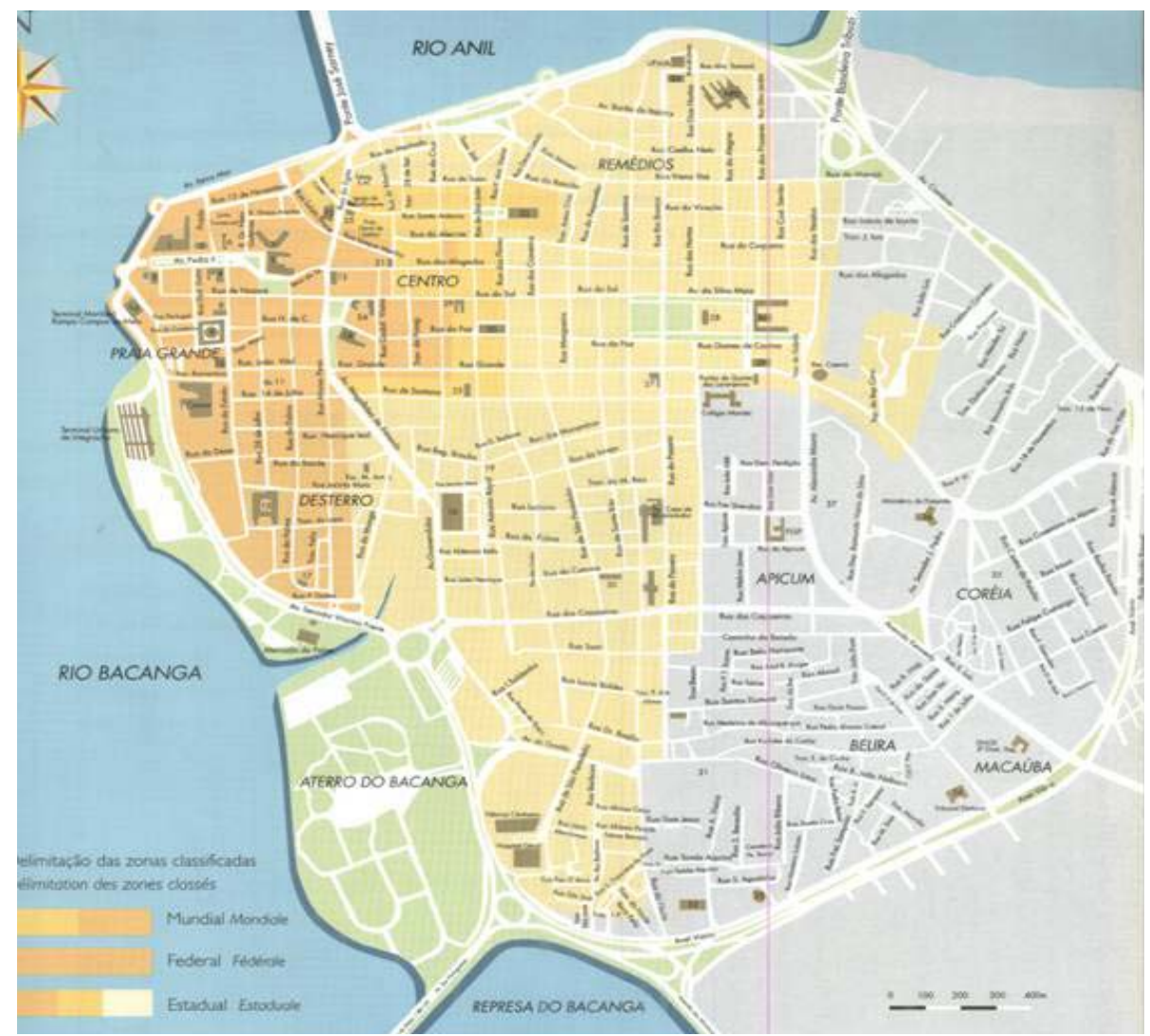

Figura 3. Mapa da região do Centro Histórico de São Luís e delimitações quanto ao Tombamento.

Fonte: Centro Histórico de São Luís - Maranhão: patrimônio mundial, 1998.

A partir de então, se percebe um afloramento do Centro Histórico em relação à sua importância. As atenções se voltam para essa região da cidade, principalmente para o Bairro da Praia Grande, onde se concentra a maior parte do acervo tombado.

Após a concessão do título, ficou evidente uma transformação na atividade turística do destino São Luís (RODRIGUES, 1999). 
"O título da UNESCO conferiu a São Luís um diferencial turístico relevante, elevando a cidade a um tipo de turismo mais qualificado" (CARVALHO, 2001, p.41).

Talvez nem tão qualificado como quantificado, já que foi nítida a elevação do número de pessoas na cidade. O que também pôde ser percebido nesse momento foi a insuficiência dos serviços prestados (RODRIGUES, 1999).

Também ficou evidente o crescimento de interesse da própria população em relação à área em questão. Isso pode ter se dado pela intensificação do tema na mídia, entre outros fatores. Mas ainda era claro o desconhecimento sobre o assunto, a comunidade ainda não percebia o Centro Histórico como parte de sua cultura e limitava o Patrimônio Cultural aos bens edificados (RODRIGUES, 1999).

"As pessoas nem ligam para a história da cidade. Mas com a cultura se relacionam. As pessoas participam muito das brincadeiras, das manifestações culturais, etc." (POPULAÇÃO, apud RODRIGUES, 1999, p. 29).

Em relação ao visitante, a curiosidade sobre o que teria de especial esse Patrimônio aguça a imaginação de muitos que vêm em busca do "excepcional valor universal" do nosso Centro Histórico. "Presume-se que grande parte dos turistas que vêm conhecer São Luís, são motivados pelo Patrimônio da Humanidade, o qual concedeu ao Centro Histórico uma notoriedade internacional" (CARVALHO, 2001, p.55).

E essa tem sido a principal forma de "exploração" desse patrimônio: apenas economicamente, deixando a desejar a sua função frente ao crescimento cultural da comunidade.

\section{A REALIDADE DA PRAIA GRANDE: TURISMO X SUSTENTABILIDADE, ASPECTOS SÓCIO-CULTURAIS.}

\section{1 - A Atividade Turística na Praia Grande}


Após o tombamento do Centro Histórico, São Luís se tornou foco de investimentos e projetos dos mais diversos que tinham como principais pretensões a restauração e preservação dessa área que agora é bem cultural do mundo. As ações se tornaram bastante perceptíveis e são enfatizadas pelos componentes do trade turístico da capital como ponto positivo para o desenvolvimento da atividade.

“Depois do título, a população passou a dar mais valor à cidade, e os governantes tão se esforçando mais para a manutenção do Centro Histórico. A preocupação com a preservação dos casarões e das casas com azulejos ficou mais rigorosa depois do título" (GASTRONOMIA, apud RODRIGUES, 1999, p.13). (sic)

O PRODETUR se destaca como uma das principais fontes de financiamento para essas ações. Em 1998, o Programa, em parceria com o BIRD realizou a implantação de sistema de rede elétrica em grande parte da Praia Grande. A obra atingiu um total de 50 hectares, equivalente à área reconhecida pela UNESCO, e teve custos estimados em R\$ 5,5 milhões (O ESTADO DO MARANHÃO, 1999).

À frente do PRODETUR no Maranhão, Luís Phelipe Andrés explicou a importância da obra para o turismo da região: "Melhorar a infra-estrutura da área do Centro Histórico é o primeiro passo para incentivar o turismo em São Luís" (O ESTADO DO MARANHÃO, 1999, CADERNO CIDADE, p. 1).

Outra implantação realizada pelo Programa de Desenvolvimento do Turismo no Nordeste foi o Projeto "Cores da Cidade", iniciado no mês de novembro de 2000. Em parceria, PRODETUR, Governo do Estado do Maranhão e Fundação Roberto Marinho trouxeram para São Luís essa experiência já realizada em cidades como Rio de Janeiro, Fortaleza, Recife e no Estado de Minas Gerais (O IMPARCIAL, 2000).

O projeto, estimado em $\mathrm{R} \$ 1,6$ milhões, teve como meta a restauração de 200 casarios que passariam por consertos nas esquadrias, pinturas, recuperação de azulejos, entre outras intervenções técnicas. Um aspecto relevante é que, entre as pretensões do projeto, estava um plano de divulgação para o Centro Histórico, 
sinalização turística adequada e ações educativas junto à comunidade (O IMPARCIAL, 2000).

Um dos projetos mais conhecidos é o Plano Maior. Desenvolvido pelo Governo do Estado, abrange todo o Maranhão, e foi dividido em cinco pólos turísticos, os quais reúnem atrativos por características e localização, assim nomeados: Florestas dos Guarás, Lençóis Maranhenses, Delta das Américas, São Luís e Chapada das Mesas.

Apresenta como objetivos:

- Alcançar um nível de qualidade turística coerente com a liderança desejada;

- Conscientizar a sociedade quanto aos benefícios sociais do turismo de qualidade;

- Aumentar o fluxo turístico.

O Plano tem como meta atingir a quantia de 1.069.500 turistas circulando entre os pólos até o ano de 2010. Os investimentos são de R 814 milhões divididos entre o setor público e o privado. A geração de empregos estipulada é de 130.700 durante a fase de implantação e de 10.300 durante a operacionalização do projeto (SEPLAN, 2000).

A Praia Grande está incluída no Pólo São Luís, de caráter históricocultural, que envolve, além da cidade de São Luís, os municípios de Alcântara, São José de Ribamar, Raposa e Paço do Lumiar (SEPLAN, 2000).

O fato de São Luís ser Patrimônio da Humanidade é apresentado como aspecto positivo para o desenvolvimento da atividade turística na capital, que visa concentrar na cidade a oferta principal, colocando as outras cidades como derivadas desta.

Entre as realizações de cunho político cita-se a emenda do Senado Federal aprovada em novembro de 2003, que viabilizou $R \$ 100$ milhões para obras em Centros Históricos de todo o Brasil, beneficiando mais de 150 projetos. 
O ano de 2004 também se destacou em relação às operações realizadas em benefício do Centro Histórico, operações essas que foram de intensa influência sobre o Bairro da Praia Grande (O ESTADO DO MARANHÃO, 2004).

Em outubro do mencionado ano, O IPHAN, com recursos provenientes do Ministério da Cultura, iniciou obras de reforma em nove casarões localizados na região do Patrimônio Histórico (O ESTADO DO MARANHÃO, 2004).

As obras consistem na estabilização e consolidação de imóveis do Centro Histórico. Os imóveis são particulares. Por conta disso, o Instituto - que prevê investimentos de $\mathrm{R} \$ 2,3$ milhões - iniciará processo jurídico para obtenção de ressarcimento dos proprietários dos imóveis (O ESTADO DO MARANHÃO, 2004).

As construções se encontravam em elevado estado de degradação, mas mesmo assim eram habitadas. Os "moradores", pessoas de baixa renda que se alojavam entre as paredes dos antigos casarios como único refúgio, foram direcionados pelo IPHAN para um abrigo (O ESTADO DO MARANHÃO, 2004a)

Posteriormente à implantação do projeto do IPHAN, São Luís recebeu a visita de representantes do Ministério das Cidades, do Ministério da Cultura e também das Missões de Cooperação Técnica Francesa e Espanhola (O ESTADO DO MARANHÃO, 2004a).

Encontravam-se estes incumbidos de discutir a realização de investimentos no Projeto de Revitalização do Centro Histórico, iniciativa da Prefeitura Municipal. Os recursos são da ordem de R 28 milhões e direcionados para a recuperação do patrimônio histórico de São Luís. O investimento, que acontece em integração com o Governo Federal, inclui ainda mais seis cidades em todo o país (O ESTADO DO MARANHÃO, 2004a).

Em entrevista ao jornal O Estado do Maranhão em 07 de novembro de 2004, Karla Nunes, coordenadora do Núcleo Gestor do Centro Histórico, enfatiza a preocupação social existente nos projetos realizados pela prefeitura, e relaciona a escolha de São Luís a esse fator. Segundo Karla "A melhoria da qualidade de vida da população é o foco principal dessas ações”. 
Um item que ilustra bem esse aspecto é a realização de adaptação de alguns casarões para habitação de famílias. O incentivo à utilização dos imóveis para fins domiciliares, o desenvolvimento de atividades produtivas e a criação de equipamentos urbanos são algumas das estratégias do Projeto (O ESTADO DO MARANHÃO, 2004a).

Serão beneficiadas cerca de 150 famílias de baixa renda, cadastradas pelo Município, que hoje se encontram em condições habitacionais irregulares e de risco. O projeto visa à criação de espaços para níveis diferentes de renda.

Há também, dentro das aspirações do projeto, com cooperação espanhola, a implantação da Oficina de Restauro, criada para capacitar jovens entre 18 e 24 anos para o restauro de casarões, instalada em dois núcleos, um na Rua da Palma, $n^{\circ} 515$, e outro na Rua Jacinto Maia, n 168. "Todas estas intervenções vão oferecer melhores condições de vida para os moradores evitando o esvaziamento da área", salienta Karla Nunes.

Uma das iniciativas mais recentes que envolvem a Praia Grande foi a assinatura do termo de adesão para a elaboração de um Plano de Preservação para o Centro Histórico. No dia 24 de novembro de 2004, São Luís foi a quinta cidade a aderir ao termo para a elaboração de um Plano de Preservação de Sítios Históricos Urbanos (PPSH), iniciativa do IPHAN em conjunto com a Prefeitura e o Governo do Estado (O ESTADO DO MARANHÃO, 2004b).

Os objetivos principais do PPSH são:

- Estabelecer diretrizes e regulamentos para orientação, planejamento e fomento das ações de preservação;

- Orientar os processos de reabilitação urbana deterioradas;

- Promover uma atuação pública integrada, tornando mais eficazes os investimentos a serem realizados nos sítios históricos;

- Promover o compartilhamento de responsabilidades entre os diversos agentes públicos envolvidos.

"O plano visa à preservação do patrimônio cultural das cidades por meio da consolidação de uma cultura urbana pautada no planejamento, na gestão compartilhada e na reabilitação urbana, com bases para processos de 
preservação sustentável do patrimônio cultural" (O Estado do Maranhão, 25 de novembro de 2004).

As iniciativas tomadas, no entanto, não evitaram a perda de alguns bens patrimoniais existentes na região. A ação do clima e do tempo é implacável frente a instalações com as características das encontradas na Praia Grande.

Os projetos, em sua maioria, atingem imóveis públicos, enquanto que os particulares sofrem pela falta de manutenção. A complexidade e alto custo de manutenção desses prédios estão entre as justificativas mais referenciadas pelos seus proprietários.

As ações de órgãos como o IPHAN, no intuito de intervir nesses prédios evitando maiores danos e até sua perda, são extraordinárias. Mas também se faz necessário implantar políticas direcionadas aos integrantes dessa comunidade, bem como, restaurar não apenas o físico, mas também o humano da Praia Grande, dando, assim, novas diretrizes aos moradores.

\section{2 - A Comunidade e a Atividade Turística}

Desde sua nomeação como Patrimônio Cultural da Humanidade, a Praia Grande vivenciou um considerável aumento no número de visitantes em busca de seus atrativos culturais. Carvalho (2001, p.41) destaca que, "o título da UNESCO conferiu a São Luís um diferencial turístico relevante, elevando a cidade a um tipo de turismo mais qualificado".

O título também proporcionou elevação nos investimentos destinados ao setor turístico no local e logo São Luís passou a figurar nos principais guias turísticos do país.

A motivação cultural tornou-se o principal motivo de viagens, sendo reflexo da grande repercussão alcançada, mostrando assim a importância do Centro Histórico no turismo maranhense (CARVALHO, 2001). 
É nesse momento que nos deparamos com uma grande dificuldade: manter São Luís como um destino turístico, quando seu principal atrativo não detém condições de suprir as expectativas dos visitantes e principalmente de suprir as necessidades de sua comunidade local. Isso é um fator relevantíssimo, já que a concretização de um plano turístico está diretamente ligada ao envolvimento dos diferentes agentes no seu processo de implantação.

Bezerra (2003, p. 117) descreve que a comunidade local "se caracteriza pelo conjunto de pessoas que co-habitam em um espaço físico delimitado no qual realizam grande parte das suas atividades cotidianas e que, além de possuírem uma cultura e identidade comuns, estão sujeitas à mesma estrutura social".

A grande divulgação que aconteceu após a titulação refere-se apenas ao patrimônio edificado na área da Praia Grande. Mas o que não se pode esquecer é que

"A construção do patrimônio cultural é um ato que depende das concepções que cada época tem a respeito do que, para quem e por que preservar. A preservação resulta, por isso, da negociação possível entre os diversos setores sociais, envolvendo cidadãos e poder público" (FUNARI e PINSKY, 2003, p. 16).

Torna-se difícil a criação do envolvimento com o patrimônio e mesmo uma intensificação dos laços com os turistas se antes essa comunidade não descobrir um valor de identificação com o patrimônio em questão.

A Comissão Mundial sobre o Meio Ambiente e Desenvolvimento (1991) destaca a importância da participação dessa comunidade nas decisões, pois assim ela poderá se articular e impor seu interesse em comum acordo com os demais setores, já que "...todo programa de revitalização deve considerar em primeiro plano o habitante da cidade. Um projeto bem resolvido, consequentemente chamará a atenção dos turistas" (CORIOLANO, 1998, p. 257).

O que se pode perceber é que na realidade da Praia Grande as políticas de planejamento e execução de ações relacionadas ao turismo pouco envolvem a comunidade. Como efeito, os moradores acabam por criar certo distanciamento e demonstram indiferença às ações e projetos desenvolvidos com finalidade turística. Essa situação reforça o desinteresse e a desinformação da comunidade local pelo 
patrimônio do bairro. Mais importuno ainda é perceber essa realidade na extensão de toda a ilha de São Luis como decorrência da própria educação que não considera disciplinas voltadas para a história e meio ambientes locais (GUEDES, 2001).

Esse distanciamento se percebe na Praia Grande com o deslocamento de grande parte de sua população para outras áreas da cidade de São Luís. Um dos fatores é a não adaptação da comunidade à nova realidade do lugar. Permanecem ali moradores mais antigos, muitos de idade avançada ou novos moradores que se apoderam dos muitos prédios e casarões em precário estado de conservação. Ainda em relação à moradia, existem necessidades quanto à melhoria na infra-estrutura básica (água, luz, saneamento) e na oferta de serviços e comércio básicos, como farmácias e padarias.

A pouca informação sobre essa nova realidade e sobre aspectos históricos da localidade potencializa esse afastamento da população. Raras são as pessoas que moram no Centro Histórico que sabem de sua formação, sua história, suas personagens. Ao turista que chega, as informações que os residentes podem dar referem-se apenas a localização espacial de ruas e endereços. A própria população se considera incapacitada de prestar informações sobre esses aspectos.

Outros fatores poucos conhecidos pela comunidade são os efeitos da atividade turística sobre a economia local, onde sua grande maioria desconhece totalmente de qualquer conseqüência gerada pela atividade (AZEVEDO, 2005).

Em 1999, pesquisa feita pelo IPES, no tópico "A percepção sobre o comportamento e identificação da população em relação à cidade", faz o seguinte comentário:

\footnotetext{
“A percepção majoritária é de que o recebimento do título de Patrimônio da Humanidade não resultou em mudanças efetivas de comportamento da população em relação à cidade. Isso se deve à falta de conhecimento do seu significado e representação por parte de ampla parcela da população" (IPES, 1999, p.5 apud GUEDES, 2001).
}

Comparando os dados com pesquisa mais recente realizada por Azevedo (2005), pode-se perceber que a realidade da comunidade é praticamente a mesma 
em relação à informação sobre o Patrimônio Histórico. No referido trabalho o índice de discordância em relação à maior participação dos moradores nas decisões referentes ao turismo local chega a $72 \%$. A não utilização dos atrativos de lazer existentes no local também atinge índice elevado, chegando a $73 \%$ de moradores que pouco utilizam esses recursos e $19 \%$ que nunca fazem uso dos mesmos (AZEVEDO, 2005).

Fica nítida a submissão da comunidade local em relação à atividade turística da forma como se desenvolve atualmente na Praia Grande. Este alerta é necessário para se repensar o valor que está sendo concedido às nossas riquezas.

Sobre isso, Guedes (2001, p. 117) menciona que

"Outro aspecto destacado que parece mostrar como o turismo pode criar prejuízo para os moradores refere-se à priorização das reformas e melhorias que são feitas nas fachadas e nas ruas, naquilo que os turistas têm acesso à vista, deixando de lado os interiores das casas e os locais mais afastados das visitações".

É importante lembrar que São Luís não se tornou Patrimônio Cultural Da Humanidade só por méritos arquitetônicos, mas, sobretudo por seus valores éticos, folclóricos e humanos. 


\section{CONSIDERAÇÕES FINAIS}

O Bairro da Praia Grande, detentor de características peculiares, tem hoje sua população residente bastante reduzida. Os que ainda lá estão já não são os que construíram ali uma vida, que presenciaram momentos de glória e decadência.

O deslocamento da comunidade para outras localidades da capital proporcionou certo abandono em algumas áreas que hoje concentram como residentes pessoas que se alojam entre prédios de condições precárias. Muitos atribuem isso às condições deficitárias do local, principalmente em relação às condições de moradia. Poucos são os locais com qualidade para atender às necessidades de uma família, e a maioria delas vive em locais que não são de sua propriedade. Os que ainda resistem são fechados em uma espécie de "subcomunidade", alheia a algumas transformações e inovações sofridas pela área. São pessoas de uma faixa etária elevada e que conhecem a história do bairro através do repasse oral de fatos e momentos vivenciados por ele. 
A atividade turística passou por uma evolução quantitativa e qualitativa indiscutível, principalmente após a titulação do Centro Histórico como Patrimônio Cultural da Humanidade. O interesse em descobrir o porquê dessa inclusão em um grupo de cidades tão singulares vem proporcionando aumento gradativo da demanda turística.

Com base nas informações adquiridas, podemos perceber que a comunidade da Praia Grande demonstra pouco conhecimento acerca da riqueza patrimonial que a localidade apresenta. Muitos têm sua relação com o bairro limitada à esfera profissional, não fazendo uso de outras estruturas existentes, como a de lazer. Um dos fatores apontados como justificativa para isso é o alto custo e até mesmo o desconhecimento sobre as atividades realizadas na área.

Sobre as ações de intervenção do Governo na área, a maior queixa é da falta de participação da comunidade nas decisões que tem o bairro como objeto. Uma observação que merece destaque é a importância dada pela comunidade para ações que tenham os indivíduos como foco principal, a necessidade de investir mais nas pessoas que na estrutura física.

Nota-se que melhorias acontecem, mas apenas para os turistas. Parte da comunidade acredita que por causa deles é que existe delegacia, que são feitas reformas em prédios e feitos investimentos em manifestações culturais no bairro.

O que se percebe é que as obras e os projetos realizados são de pouca influência sobre as pessoas que residem ou trabalham na área, principalmente em atividade que não seja diretamente relacionada ao turismo. Constata-se que existe até mesmo uma certa aversão por parte de alguns indivíduos em relação à atividade turística. A comunidade entende que com o turismo os investimentos são direcionados somente para esse fim, e as necessidades básicas da comunidade são esquecidas ou aparecem como complemento de projetos de cunho turístico.

É preciso, então, não só restaurar os velhos prédios, mas criar programas que possam criar novos hábitos no cotidiano desses moradores na busca pelo desenvolvimento de um turismo sustentável, onde a comunidade seja parte integrante do processo, pois a preservação é tarefa de todos. 
Chega-se à conclusão que é necessário fazer uma revisão dos projetos que dizem respeito à comunidade e daqueles que não a incluem em suas diretrizes, essa comunidade que é sensível às mudanças e que se sente preterida em relação às decisões que lhe dizem respeito.

É preciso, portanto, estimular essa comunidade a conhecer suas origens, a perceber sua importância, repassando esses conhecimentos e valores para as gerações futuras, contribuindo, assim, para a preservação do Patrimônio Cultural de São Luís.

\section{REFERÊNCIAS}

AGUIAR, Maria Rodrigues de; DIAS, Reinaldo. Fundamentos do Turismo: conceitos, normas e definições. Campinas, SP: Editora Alínea, 2002.

ALMEIDA, Maria do Rosário Guimarães. Diretrizes para a apresentação de monografia. São Luís: Faculdade São Luís, 2004.

ANDRADE, José Vicente de. Turismo - Fundamentos e Dimensões. São Paulo: Ática, 2002.

ALBANO, Celina; Murta, Stela Maris (Org.). Interpretar o Patrimônio: Um exercício do olhar. Belo Horizonte: UFMG: Território Brasilis, 2002.

ANDRÉS, Luiz Phelipe de Carvalho Castro (Coord.). Centro Histórico de São Luís Maranhão: patrimônio mundial. São Paulo: Audichromo Editora, 1998.

ARCHER, Brian; COOPER, Chris. Os impactos positivos e negativos do turismo. [s.I.], [s.n.],199-.

AVIGHI, Carlos Marcos. Turismo, Globalização e Cultura. In: LAGE, Beatriz Helena Gelas; MILONE, Paulo César (Org.). Turismo: Teoria e Prática. São Paulo:

Atlas,2000. 
AZEVEDO, Kiara Mesquita de. "São Luís Patrimônio Cultural da Humanidade": efeitos sociais, culturais e econômicos da área da Praia Grande na perspectiva turística. 2005. Monografia (Curso de Turismo) - Faculdade de Ciências Humanas e Sociais Aplicadas São Luís, São Luís, 2005.

AZEVEDO, Kiara Mesquita de. Condicionantes para a Gestão Compartilhada de Sítios Históricos e Urbanos. Registro pessoal de aula. Universidade de Brasília, 2006.

AZEVEDO, Kiara Mesquita de. Preservação Urbana das Cidades. Registro pessoal de aula. Universidade de Brasília, 2006a.

AZEVEDO, Kiara Mesquita de. Sítios Históricos e Urbanos e Desenvolvimento Sustentável. Registro pessoal de aula. Universidade de Brasília, 2006b.

BARRETTO, Maragrita. Turismo e legado cultural: As possibilidades do planejamento. Campinas, SP: Papirus,2000.

BARRETTO, Margarita. Manual de iniciação ao estudo do turismo. Campinas, SP: Papirus, 2005.

BATISTA, Maria Nelma Pires. Um estudo sobre os tipos de morada do Centro Histórico de São Luís como atrativo turístico diferenciado. 1999. Monografia (Curso de Turismo) - Universidade Federal do Maranhão, São Luís, 1999.

BEZERRA, Deise Maria Fernandes (Org.). Planejamento e Gestão em Turismo. São Paulo, SP: Roca, 2003.

BO, João Batista Lamari. Proteçãodo Patrimônio na UNESCO: ação e significados. Brasília: UNESCO, 2003.

BOSQUE MOREL, Joaquín. O Patrimônio da Humanidade. In: YÁZIGY, E.; CARLOS, A.F.C.; CRUZ, R.C.A. da (Org). Turismo, Paisagem e Cultura. São Paulo: HUCITEC, 1999.

BRASIL. Constituição (1988). Constituição da República Federativa do Brasil. Brasília, DF: Senado Federal Subsecretaria de Edições Técnicas, 2005.

BRITO, Marcelo. As cidades históricas como urbs: corpo e alma do patrimônio. Chronica Brasil, p. 22 -23, set., 2004.

BRITO. Marcelo. Quem disse que eu não preservo? Chronica Brasil, p. 30, out. 2004 a. 
BURNS, Peter M. Turismo e antropologia: uma introdução. São Paulo: Chromos, 2002.

CARVALHO, Mirella Nascimento. A importância da preservação e restauração dos azulejos para o Turismo na cidade de São Luís. 2001. Monografia (Curso de Turismo) - Universidade Federal do Maranhão, São Luís, 2001.

COMISSÃO MUNDIAL SOBRE O MEIO AMBIENTE E DESENVOLVIMENTO. Nosso Futuro Comum. 2ed. Rio de Janeiro: FGV, 1991

COELHO, Olinio Gomes P. Do Patrimônio Cultural. Rio de Janeiro: [s.n.], 1992.

CORIOLANO, Luzia Neide Menezes Teixeira (Org.). Turismo com Ética. Fortaleza: UECE, 1998.

FONSECA, Maria Cecília Londres. O Patrimônio em processo: Trajetória da política federal de preservação no Brasil. Rio de Janeiro: UFRJ:IPHAN, 1997.

FUNDAÇÃO BRASILEIRA PARA O DESENVOLVIMENTO SUSTENTÁVEL. Escala Histórica do Desenvolvimento Sustentável. (200-). Disponível em:

http://www.fbds.org.br/rubrique.php3?id_rubrique=28. Acesso em: 08 dez. 2006.

FOLHA ONLINE. Desenvolvimento Sustentável busca crescimento sem destruição. Folha Ciência: 2003. Disponível em:

http://www1.folha.uol.com.br/folha/ciencia/ult306u9273.shtml. Acesso em: 09 dez. 2006.

FUNARI, Pedro Paulo; PINSKY, Jaime. Turismo e Patrimônio Cultural. São Paulo: Contexto, 2003.

GOODEY, Brian; MURTA, Stela Maris. Interpretação para o Turismo Sustentado: um guia. Belo Horizonte: SEBRAE/MG, 1995.

GUEDES, Kláutenys Dellene Barros. Políticas de Preservação do Centro Histórico de São Luís. Recife [s.n.], 2001.

HORTA, Maria de Lourdes Parreiras. Guia Básico de Educação Patrimonial.

Brasília: Instituto do Patrimônio Histórico e Artístico Nacional, Museu Imperial, 1999.

KRIPPENDORF, Jost. Sociologia do Turismo: para uma nova compreensão do lazer e das viagens. São Paulo: Aleph, 2001. 
MENDES, Marina Cecato. Desenvolvimento Sustentável. 200-. Disponível em: http://educar.sc.usp.br/biologia/principal.html. Acesso em: 08 dez. 2006.

MARTINS, Ananias. São Luís: Fundamentos do Patrimônio Cultural - séc. XVII, XVIII E XIX. São Luís: Sanluiz, 1999.

MEIRELES, Mário Martins. História do Maranhão. São Paulo: Siciliano,2001.

MEIRELES, Mário Martins; TEIXEIRA, Ana Otília Meireles. O Projeto Praia Grande. São Luís: [s.n.], 1979.

MOLETTA, Vânia Florentino. Turismo Cultural. Porto Alegre: SEBRAE/RS, 1998.

O ESTADO DO MARANHÃO. São Luís, 04 fev. 1999.

O ESTADO DO MARANHÃO. São Luís, 13 nov. 2003.

O ESTADO DO MARANHÃO. São Luís, 08 out. 2004.

O ESTADO DO MARANHÃO. São Luís, 07 nov. 2004a.

O ESTADO DO MARANHÃO. São Luís, 25 nov. 2004b.

OLIVEIRA JÚNIOR, Diacir Andrade de. A viabilidade e importância ecnômica do turismo em São Luís do Maranhão para as próximas décadas. 2000. Monografia (Curso de Ciências Econômicas) - Centro Universitário do Maranhão, São Luís, 2000.

O IMPARCIAL. São Luís, 24 nov. 2000.

ORGANIZAÇÃO MUNDIAL DO TURISMO. Guia de Desenvolvimento do Turismo Sustentável. Porto Alegre: Bookman, 2003.

PEREIRA, Epitácio Cafeteira Afonso. Reviver. Brasília: Senado Federal, Centro Gráfico, 1994.

RIBEIRO, Diva Lacerda Nascimento; Carvalho, Teresa Cristina Saraiva de. Turismo Cultural: estudo sobre o grau de expectativa e satisfação do turista que visita o bairro da Praia Grande, São Luís - MA. 2004. Monografia (Curso de Turismo) Faculdade de Ciências Humanas e Sociais Aplicadas São Luís, São Luís, 2004.

RÊGO, Oziana da Silva. São Luís Patrimônio Histórico da Humanidade. São Luís, [s.n.], 1998. 
RODRIGUES, Linda Maria. Pesquisa qualitativa/Entrevista em Profundidade Turismo em São Luís. São Luís: [s.n.], 1999.

SÍTIO VEGETARIANO. Relatório da ONU culpa homem por aquecimento global. 02 fev. 2007. Disponível em:

http://www.vegetarianismo.com.br/sitio/index.php?option=com_frontpage\&ltemid=11 0. Acesso em: 11 fev. 2007.

SWARBROOKE, John. Turismo Sustentável: turismo cultural, ecoturismo e ética, vol. 5. São Paulo: Aleph, 2000.

UNESCO, Barsa Planeta. Patrimônio da Humanidade: América Central e do Sul. São Paulo: São Marcos Editora, 2002.

VAGALUME. São Luís, ano VI, n. 21. ago./set., 1993

VOU DE MOCHILA. Disponível em: http://www.voudemochila.com.br/cidades. 2007. Acesso em: 23 mar. 2007. 